\title{
Estimating Groundwater Mixing Ratios from Vertical Flux Processes due to Excessive Groundwater Pumping Using Hydrogeochemical Parameters and Nitrate Concentrations in the Bandung Basin, Indonesia
}

\author{
Ahmad Taufiq ${ }^{1,2}$, Takahiro Hosono ${ }^{1,5}$, Irwan Iskandar ${ }^{3}$, Agus J. Effendi ${ }^{4}$ and Lambok M. Hutasoit ${ }^{2}$ \\ ${ }^{1}$ Kumamoto University, Graduate School of Science and Technology, Kumamoto, Japan; (correspondence author email address: ahmad.taufiq@pu.go.id) \\ ${ }^{2}$ Faculty of Earth Science and Technology, Bandung Institute of Technology, Bandung, Indonesia \\ ${ }^{3}$ Faculty of Mining and Petroleum Engineering, Bandung Institute of Technology, Bandung, Indonesia \\ ${ }^{4}$ Faculty of Civil and Environmental Engineering, Bandung Institute of Technology, Bandung, Indonesia \\ ${ }^{5}$ Priority Organization for Innovation and Excellence, Kumamoto University, Kumamoto, Japan
}

doi: $10.4154 / g c .2018 .19$

Article history:

Manuscript received June 30, 2017

Revised manuscript accepted September 28, 2018

Available online October 24, 2018

\begin{abstract}
One crucial task in groundwater research and management is the estimation of groundwater mixing ratios. Here, estimations of mixing ratios are presented systematically and spatially for shallow and deep groundwater in some areas of excessive groundwater pumping with different magnitudes of groundwater drawdown. The mixing ratios are estimated using two methods: (1) the total mixing ratio using all parameters, and (2) the mixing ratio using nitrate concentrations. The values for the total mixing ratio indicate that mixing between the shallow and the deep groundwater clearly occurs in all three depression areas, but with different ratios. The spatial distribution map of the total mixing ratio clearly shows that the largest mixing ratio occurs near the center of the cone of depression, and that the ratio decreases gradually away from the center of the depression area. There is a positive correlation among total mixing ratios, CFC-12 concentrations, and modeled vertical flux. Remarkably, the highest correlation is found between the correlation of the total mixing ratio and magnitude of vertical flux in the largest drawdown area. Meanwhile, comparison of the mixing ratio calculations by the different methods showed insignificant correlation which means nitrate is ineffective as the prevailing contaminant tracer for deep groundwater in this basin. Overall, this study concludes that the method of total mixing ratio using all chemical parameters is the most effective and consistent with previous methods. This study provides further proof that groundwater mixing between the shallow and deep groundwater systems has clearly occurred in the Bandung basin as an impact of excessive groundwater pumping.
\end{abstract}

Keywords: excessive pumping; groundwater mixing; mixing ratio; nitrate isotopes; Bandung Basin, Indonesia variations of the end-members. Under these conditions, it would be worth basing the calculation of total mixing ratios on all the available parameters measured because the uncertainty of estimation can be reduced (RUEEDI et al., 2005).

Nowadays, industrialization, urbanization, and population growth has created a host of environmental hazards, reflected in subsurface environmental problems (FOSTER \& CHILTON, 2003). Moreover, in Asian cities as very rapidly developing areas, subsurface environmental problems are mostly caused by excessive groundwater pumping, groundwater drawdown and groundwater contamination (TANIGUCHI et al., 2008; JAGO-ON et al., 2009; HOSONO et al., 2011). Specifically, in Indonesia, a significant groundwater drawdown has been reported throughout big cities such as Jakarta, Bandung, and Semarang, starting from increasing of water demand leading to excessive groundwater pumping (WIRAKUSUMAH \& DANARYANTO, 2004). This excessive groundwater pumping could result in mixing processes between groundwaters from different systems or aquifers. It might cause dilution of the groundwater, with the potential to cause the degradation of groundwater quality.

In the Bandung basin, human and industrial activities have influenced the groundwater condition. Since the early 1970s, many textile industrial activities have taken place in the Bandung basin. Industrialization, along with urbanization has caused a geneous database of chemical and isotopic data and high spatial 
significant increase in water demand in the Bandung Basin with the biggest groundwater consumer being the textile industries. Consequently, there are three large groundwater depression areas within these industrial and urban areas, which have different magnitudes of groundwater drawdown. In the study area, excessive groundwater pumping has created a vertical downward flux from the shallow to deeper aquifers, which has caused groundwater mixing in those areas. Mixing was indicated by observed high CFC-12 concentrations in deep groundwater and the vertical flux was confirmed by modeling (TAUFIQ et al., 2017).

To further evaluate mixing in the groundwater, it is necessary to calculate mixing ratios that can be achieved using hydrogeochemical parameters. Furthermore, it is also necessary to increase our understanding of the mixing process, and to further prove that there was groundwater mixing due to excessive pumping in the Bandung basin. In this paper, the calculation of mixing ratios between shallow and deep groundwater will be presented systematically and spatially. In the first part of this paper, the total mixing ratio will be determined by involving all measured parameters to eliminate possible observer bias and reduce estimation uncertainty. Meanwhile, in the second part, the mixing ratio will be calculated by involving only one parameter, nitrate, as a contaminant tracer. For further evaluation of groundwater mixing, the estimated mixing ratios will be compared for three depression areas. The results are also compared with results from previous investigations. Finally, the two methods of calculating mixing ratios will be evaluated both scientifically and practically.

\section{STUDY AREA}

Bandung Basin is located in the centre of West Java, Indonesia and is one of the most developed basins in Indonesia. Bandung is the capital of West Java province, the most densely populated province in Indonesia, and the centre of its textile industry. The Bandung Basin has an area of about $2300 \mathrm{~km}^{2}$, includes five administrative regions, and currently has a population of more than 7 million people. The basin is surrounded by mountains up to $2400 \mathrm{~m}$ high, consisting of late Tertiary and Quaternary volcanic deposits, forming an intramontane basin. The geology of this basin is classified into the following three formations, oldest first
(HUTASOIT, 2009): Cikapundung Formation, Cibereum Formation and Kosambi Formation (Figure 1). The oldest Cikapundung Formation is composed of conglomerates, and compacted breccia, tuff, and andesite lava and forms the basement of the groundwater basin. The overlying Cibeureum Formation is a fan-shaped distribution of volcanic deposit of Late PleistoceneHolocene age. The youngest Kosambi formation is distributed in the centre of this basin, as a lake deposit, and its lithology consists of unconsolidated claystone, siltstone, and sandstone of Holocene age.

Hydrogeologically, the Bandung Basin can be divided into two groundwater systems: a shallow one and a deep groundwater system. The shallow groundwater is found in the Kosambi formation or the unconfined aquifer with a local flow that is accessed from dug wells with depths much less than $20 \mathrm{~m}$. Meanwhile, the deep groundwater is allied with the Cibeureum formation as a semiconfined and confined aquifer with an intermediate and regional flow. It is accessed via drilled wells mainly in the industrial area with well depths exceeding $40 \mathrm{~m}$. To calculate mixing amounts, it is assumed that there is a mixture of water from the two aquifer systems: shallow and deep groundwaters in the depression areas due to excessive pumping of this basin. There are three large groundwater depression areas in the industrial complex: Cimahi area (CMHI), Rancaekek area (RCK), and Dayeuhkolot area (DHYK) (Figure 1b), that are well-known by their codes as the investigation areas. Monitoring of the deep groundwater levels was accomplished by the basin authority: the Office of Energy and Mineral Resources, West Java Province. The results show that for the deep groundwater potential over the past twenty years the $\mathrm{CMHI}$ area has the largest rate of groundwater drawdown decline: $1-2 \mathrm{~m} /$ year, the RCK area is declining at a rate of $0-1 \mathrm{~m} /$ year, and the DHYK area is declining at a slightly lower rate stil. According to TAUFIQ et al. (2017), the groundwaters in the Bandung Basin could be determined based on their hydrogeochemical types, which are: $\mathrm{a} \mathrm{Ca}-\mathrm{HCO}_{3}$ type for the shallow aquifer and a $\mathrm{Na}-\mathrm{HCO}_{3}$ type for the deep groundwater. But there were some seemingly random occurrences of the $\mathrm{Ca}-\mathrm{HCO}_{3}$ type in the deep groundwater at three depression areas that were identified as the result of groundwater mixing.
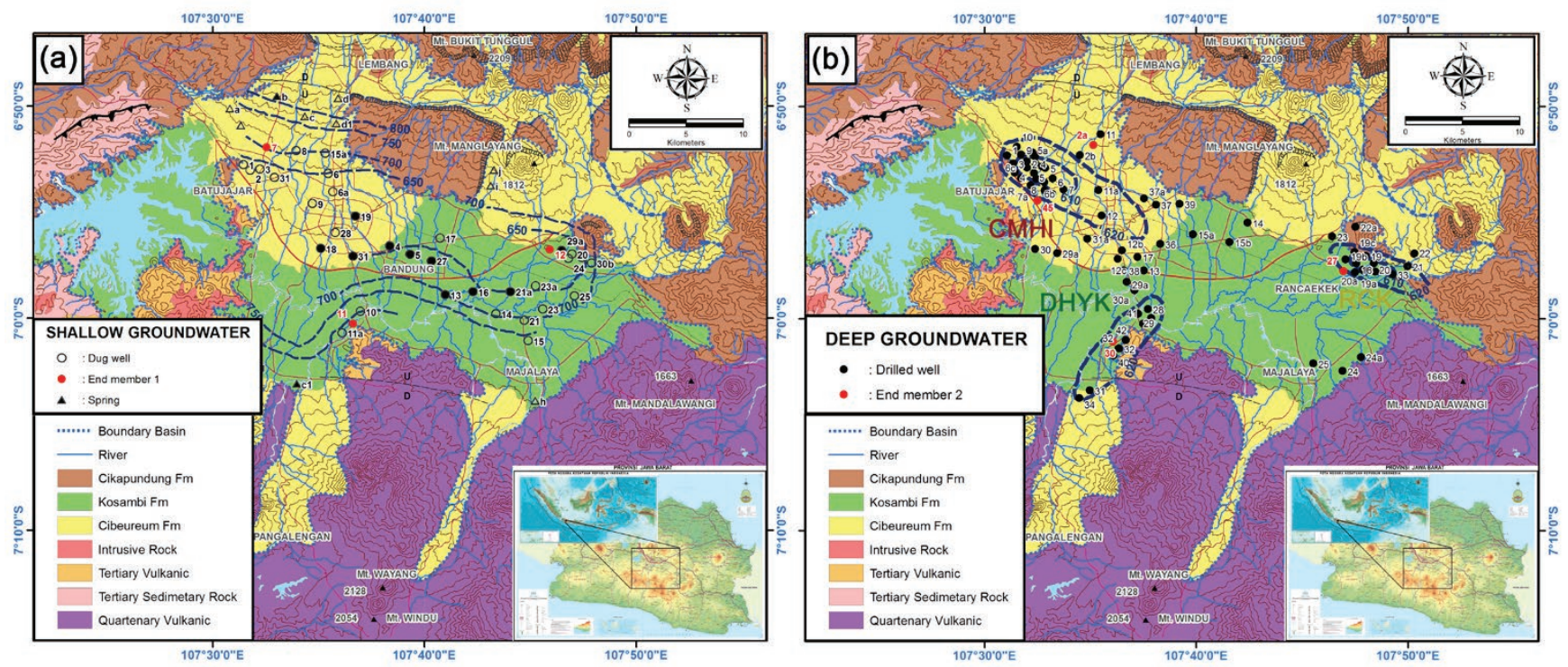

Figure 1. Location map of the sampling points plotted on a geological map (HUTASOIT, 2009): a) for shallow groundwater, b) for deep groundwater. The points with potential contours (TAUFIQ et al., 2017) and the locations of their end-members. The shallow groundwater flows from the periphery to the centre of the basin meanwhile, the deep groundwater was identified where there were three depression areas: CMHI area, RCK area and DHYK area. 


\section{METHODOLOGY}

\subsection{Sampling and methods}

In this study, all the hydrogeochemical data were used for the shallow and deep groundwater that have been obtained for determining water composition in the Bandung Basin (TAUFIQ et al., 2017) (Appendix 1). A total of 40 shallow and 65 deep groundwater samples were collected between May to July 2015. Some in-situ tests, such as temperature, $\mathrm{pH}$, dissolved oxygen (DO), electrical conductivity (EC), and oxidation-reduction potential (ORP) of the water samples were measured in the field with $d$ quality minimal atmospheric contact, using a portable meter of WM-32EP (TOA-DKK Co, Tokyo Japan). Water samples were collected separately for each analytical procedure (methods detailed in TAUFIQ et al., 2017): major ions $\left(\mathrm{Na}^{+}, \mathrm{K}^{+}, \mathrm{Ca}^{2+}, \mathrm{Mg}^{2+}\right.$, $\mathrm{Cl}^{-}, \mathrm{SO}_{4}{ }^{2-}$ and $\left.\mathrm{HCO}_{3}{ }^{-}\right)$and stable isotopes $\left(\delta^{18} \mathrm{O}\right.$ and $\left.\delta^{2} \mathrm{H}\right)$. For some trace element concentrations, $\mathrm{Fe}^{2+}$ and $\mathrm{Mn}^{2+}$ concentrations were analyzed using an inductively coupled plasma mass spectrometer (ICP-MS) (NexION300D, PerkinElmer, USA) and using standard mode and kinetic energy discrimination (KED) mode. Replicate analyses were carried out to check the precision and accuracy of the results. Precision was better than $\pm 10 \%$, evaluated from the repeated measurement of standard reference solutions with certified concentrations.

For analysis of nitrate concentrations and nitrate isotope ratios, water samples were also collected separately (methods detailed in HOSONO et al., 2013; 2014): Nitrate concentration was measured by ion chromatography (DIONEX ICS 1600, Thermo Fisher Scientific Inc., USA); and the nitrate isotope compositions were determined following the denitrifier method of SIGMAN et al. (2001) and CASCIOTTI et al. (2002). Using this method, a sample containing nitrate was converted to nitrous oxide $\left(\mathrm{N}_{2} \mathrm{O}\right)$ by denitrifying bacteria that lack $\mathrm{N}_{2} \mathrm{O}$-reductase activity. This was then stripped from the sample vial using helium carrier gas, purified using cryogenic trapping (Thermo Fisher Precon System), chromatographically separated (Thermo Fisher Gas Bench), and analyzed using mass spectrometry (Thermo Fisher Delta V Advantage). Isotope values were calibrated using the United States Geological Society (USGS) and International Atomic Energy Agency (IAEA) nitrate standards: USGS-34, USGS-35, and IAEA-N3. Based on replicate measurements of standards and samples (n $1 / 4288$ ), the analytical precisions for $\delta^{15} \mathrm{~N}_{-} \mathrm{NO}_{3}{ }^{-}$and $\delta^{18} \mathrm{O}_{-} \mathrm{NO}_{3}{ }^{-}$were better than $\pm 0.2 \%$ and $\pm 0.3 \%$, respectively. The nitrogen isotope ratio for powdered samples was determined by mass spectrometry interfaced with a CNS elemental analyzer (Thermo Fisher Flash 2000). The analytical precision of the analysis was better than $\pm 0.15 \%$.

\subsection{Calculation method of the mixing ratio}

\section{Nomenclature}

C concentration

$\mathrm{P}$ groundwater parameter

S sample

$\sigma$ standard deviation

m mixing ratio of a parameter $i$

$n$ total number of parameters

w weight of parameter

The calculation of mixing ratios in this study was applied using some equations from the following procedures (RUEEDI et al., 2005; HAN et al., 2010). Firstly, the calculation used all the parameters $(\mathrm{S})$ for two end-members: end-member 1 for shallow groundwater $\left(\mathrm{C}_{1}\right)$ and end-member 2 for deep groundwater $\left(\mathrm{C}_{2}\right)$. The end members were the most representative samples which had natural groundwater quality. The two previous studies were considered that had characterized natural groundwater in the
Bandung basin. As mentioned by WAGNER \& SUKRISNO (1998) and TAUFIQ et al. (2017), the shallow groundwater was characterized generally as an $\mathrm{Ca}-\mathrm{HCO}_{3}$-type, generally low oxygen levels, elevated $\mathrm{Fe}^{2+}$ concentration, elevated $\mathrm{Mn}^{2+}$ concentrations, and high CFC-12 concentration, meanwhile the deep groundwater was characterized generally by the $\mathrm{Na}-\mathrm{HCO}_{3}$-type, with elevated $\mathrm{Cl}^{-}$concentrations and no CFC-12 concentration.

The estimation began by calculating the mixing ratio $\left(\mathrm{m}_{\mathrm{p}}\right)$ for every concentration $(\mathrm{C})$ of each parameter $(\mathrm{p})$ using an equation (1). The equations (1) - (4) were applied by following RUEEDI et al. (2005);

$$
\mathrm{m}_{\mathrm{P}}=\frac{\mathrm{C}_{\mathrm{S}, \mathrm{P}}-\mathrm{C}_{2, \mathrm{P}}}{\mathrm{C}_{1, \mathrm{P}}-\mathrm{C}_{2, \mathrm{P}}}
$$

At every parameter, its standard deviation $\left(\sigma_{\mathrm{p}}\right)$ was estimated using equation (2);

$$
\sigma_{P}=\frac{1}{\left(C_{1, P}-C_{2, P}\right)^{2}} \sqrt{\sigma_{S, P}^{2}\left(C_{1, P}-C_{2, P}\right)^{2}+\sigma_{1, P}^{2}\left(C_{S, P}-C_{2, P}\right)^{2}+\sigma_{2, P}^{2}\left(C_{S, P}-C_{1, P}\right)^{2}}
$$

The total mixing ratio $(\overline{\mathrm{m}})$ was calculated by averaging the ratios of all parameters (n) using equation (3), and the usefulness of each parameter or the weight $\left(\mathrm{w}_{\mathrm{p}}\right)$ using equation (4);

$$
\begin{gathered}
\overline{\mathrm{m}}=\frac{\sum_{\mathrm{P}=1}^{\mathrm{n}} \mathrm{m}_{\mathrm{P}} \mathrm{W}_{\mathrm{P}}}{\sum_{\mathrm{P}=1}^{\mathrm{n}} \mathrm{W}_{\mathrm{P}}} \\
\mathrm{w}_{\mathrm{P}}=\frac{1}{\sigma_{\mathrm{P}}^{2}}
\end{gathered}
$$

Next, the mixing ratio was estimated using only one parameter and only using equation (1). The parameter was nitrate concentration, selected considering its nitrate isotopes, the stable isotope ratios of nitrogen and oxygen. It was selected because the nitrate concentration is an ongoing contaminant in this basin. Moreover, since the 1970s, nitrate isotopes are a powerful tracer for revealing concealed contaminant sources (i.e. KREITLER, 1979; KAPLAN \& MAGARITZ, 1986; HOSONO et al., 2013). The possible source of Nitrate could be identified from groups of isotope composition ranges, using the approach of KENDALL, (1998) and SINGLETON et al. (2007): Group A (the nitrification of $\mathrm{NH}_{4}{ }^{+}$in fertilizer; -8 to $+5 \%$, -5 to $+15 \%$, for $\delta^{15} \mathrm{~N}_{-} \mathrm{NO}_{3}{ }^{-}$and

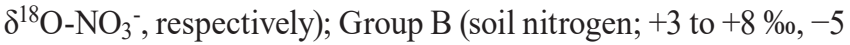
to $+15 \%$ ); Group $\mathrm{C}$ (manure and sewage-derived $\mathrm{NO}_{3}-0$ to +25 $\% 0,-5$ to $+15 \%$ ); Group D (fertilizer ; -5 to $+8 \%,+15$ to +25 $\%$ ), Group E (precipitation ; -5 to $+10 \%$ and +18 to $+70 \%$ ), respectively (Figure 5a).

\section{RESULTS}

\subsection{Selection of end members}

Firstly, two end-members were selected, one for shallow groundwater and one for deep groundwater, based on assumptions of their major differences in terms of hydrogeochemical signatures and based on the groundwater system of the study area. The two end-members for the dual groundwater system in the Bandung basin were:

End-member 1 - shallow groundwater. This groundwater was characterized by elevated $\mathrm{Ca}^{2+}$ concentrations of approximately $50 \mathrm{mg} / 1$, elevated $\mathrm{HCO}_{3}{ }^{-}$concentrations of approximately $200 \mathrm{mg} / \mathrm{l}$, low $\mathrm{Na}^{+}$concentrations around $35 \mathrm{mg} / \mathrm{l}, \mathrm{K}^{+}$concentrations around $10 \mathrm{mg} / \mathrm{l}, \mathrm{Mg}^{2+}$ concentrations round $15 \mathrm{mg} / \mathrm{l}$, low $\mathrm{Cl}^{-}$and low concentrations of around $40 \mathrm{mg} / 1$ (WAGNER \& SUKRISNO, 1998). The $\mathrm{Ca}^{2+}$ concentration and CFC-12 concen- 
trations in shallow groundwater were higher than in the deep groundwater (TAUFIQ et al., 2017).

End-member 2 - deep groundwater. This groundwater was characterized by elevated $\mathrm{Na}^{+}$concentrations of approximately $50 \mathrm{mg} / \mathrm{l}$, elevated $\mathrm{Mg}^{2+}$ concentrations around $20 \mathrm{mg} / \mathrm{l}$, elevated $\mathrm{Cl}^{-}$concentrations of around $45 \mathrm{mg} / 1$, and $\mathrm{HCO}_{3}{ }^{-}$concentrations of about $250 \mathrm{mg} / \mathrm{l}$, low $\mathrm{Ca}^{2+}$ concentrations around $40 \mathrm{mg} / \mathrm{l}$, low $\mathrm{K}^{+}$concentrations around $10 \mathrm{mg} / 1$ (WAGNER \& SUKRISNO, 1998). Low or negative values for ORP (Oxidation-Reduction Potential) and no CFC-12 concentrations (TAUFIQ et al., 2017) mean that this groundwater is characterized by either reducing conditions of the confined aquifer or that the water is old and uncontaminated.

Notably, persistent contaminants or 'unnatural' substances that affect the major chemistry or isotopic groundwater signature were excluded from the definition of the natural parameters. According to WAGNER \& SUKRISNO (1998): the shallow groundwater had elevated $\mathrm{Fe}^{2+}$ concentration if it's values exceed $1 \mathrm{mg} / \mathrm{l}$ (defined as elevated substance 1) and $\mathrm{Mn}^{2+}$ concentration if it's values exceed $0.5 \mathrm{mg} / \mathrm{l}$ (defined as elevated substance 2). Meanwhile, according to TAUFIQ et al. (2017): the shallow groundwater had elevated levels of CFC-12 concentration if this exceeds $>576$ pptv (defined as elevated substance 3) and for the deep groundwater, it had elevated substances if CFC-12 concentrations were observed, as a young (modern) tracer. In addition, nitrate concentration was also identified as elevated substance 4 . Since there was a study about its natural background values, the cut-off level of $3 \mathrm{mg} / \mathrm{l}$ was chosen based on the observations in the Bandung Basin (TAUFIQ et al., 2018).

The selection of end members was undertaken by taking samples that had no unnatural substances and were located at the furthest point possible from a potential contaminant source for every depression areas. The shallow groundwater sample was the closest location to the recharge area or the periphery of this basin and the deep groundwater was the furthest location from the depression area or industrial area. A sample number S7 was chosen as end-member 1 (from 4 samples) because its location was the closest to the northern area; and D46 for end-member 2
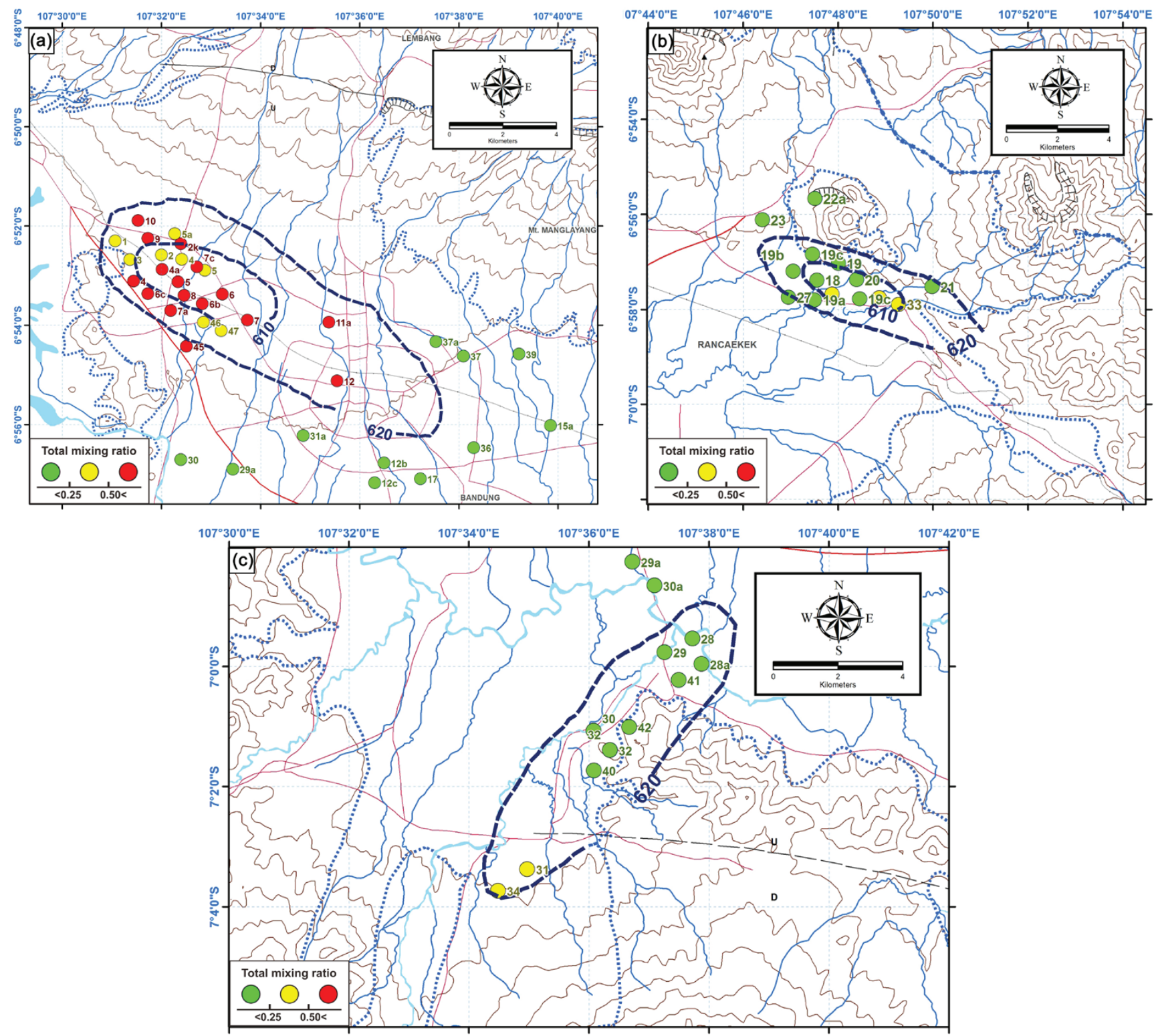

Figure 2. The spatial distribution map of the total mixing ratios for all samples of deep groundwater in the depression areas: CMHI area (a), RCK area (b), and DHYK area (c). The points with potential contours from observation wells (TAUFIQ et al., 2017). 
(from 15 samples) because it was located furthest away from the depression area. Selection of end members in the CMHI area is presented in Table 1, and plotted in Figure 1. Using the same approach for the RCK and DHYK areas, S12 and S11 were selected as end-members of the shallow and groundwater samples respectively; and D27 and D30a as end members of deep groundwater samples. The selection of the end members for the RCK and DHYK area is presented in Appendix 1.

\subsection{Calculation of the total mixing ratio}

To calculate the total mixing ratio, all the above equations were applied. The calculation was ideal for estimating the total mixing ratio because it used all the important parameters, 7 major ions, and 2 stable isotopes. The calculated total mixing ratios vary from 0.01 to 0.69 . These results indicate that there was mixing in deep groundwater due to a recharging vertical flux from the shallower to the deeper waters. In the CMHI area, the mean of the total mixing ratio was 0.43 which is larger than the other areas. The results are presented in Appendix 2, plotted in Figure 3a and summarized in Table 2.

The spatial distribution pattern of mixing ratios shows a clear relationship to the contour pattern of the depression areas (as presented in Figure 2). The spatial distribution map of the total mix- ing ratio in the CMHI area clearly shows that a larger mixing ratio was found close to the center of the depression cone, and the mixing ratio gradually decreases towards the edges of the cone. This pattern was also observed in the RCK and DHYK areas, but is less pronounced. It is due to the biggest vertical flux of water occurring at the centre of the cone, meaning that the deepest drawdown causes subsequent groundwater mixing between shallow and deep aquifers. Thus, the gradual decrease to the edge of the depression zone is also spatially controlled by the depth of drawdown. The mixing pattern in the CMHI area where the greatest drawdown occurred is more spatially related to the cone of depression than for the other areas.

\subsection{Calculation of the nitrate mixing ratio}

The range of nitrate concentrations is between 0.20 and 20.69 $\mathrm{mg} / \mathrm{l}$; none of the analyzed samples $(\mathrm{n}=93)$ exceeded the World Health Organization limit of $50 \mathrm{mg} / \mathrm{l}$ for both the shallow and deep groundwaters in this basin, but some of the shallow groundwaters exceeded Indonesia's standard of $10 \mathrm{mg} / \mathrm{l}$. Notably, in the Bandung Basin, the shallow groundwater tended to be more nitrate enriched than the deep one, as depicted in Figure 4. This enriched trend of both groundwaters will be compared in detail in a future paper (TAUFIQ et al., 2018 in press).
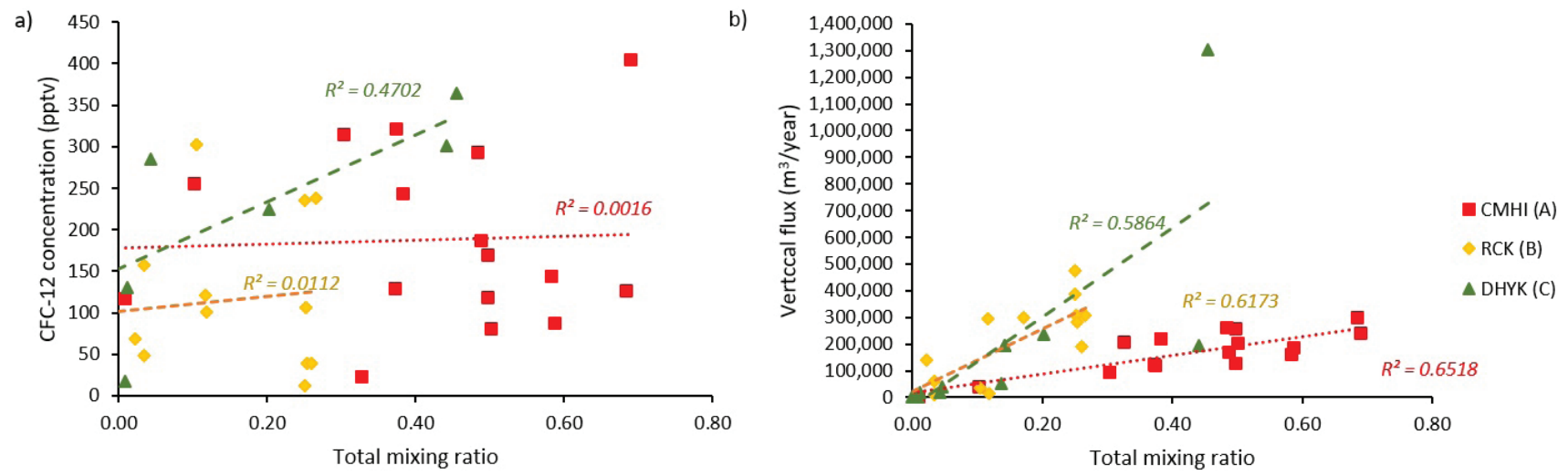

Figure 3. Correlation between (a) magnitude of CFC-12 concentrations and the total mixing ratio, (b) magnitude of the vertical flux and the total mixing ratio. The variously colored dashed lines indicate the regression line of each correlation for each area.
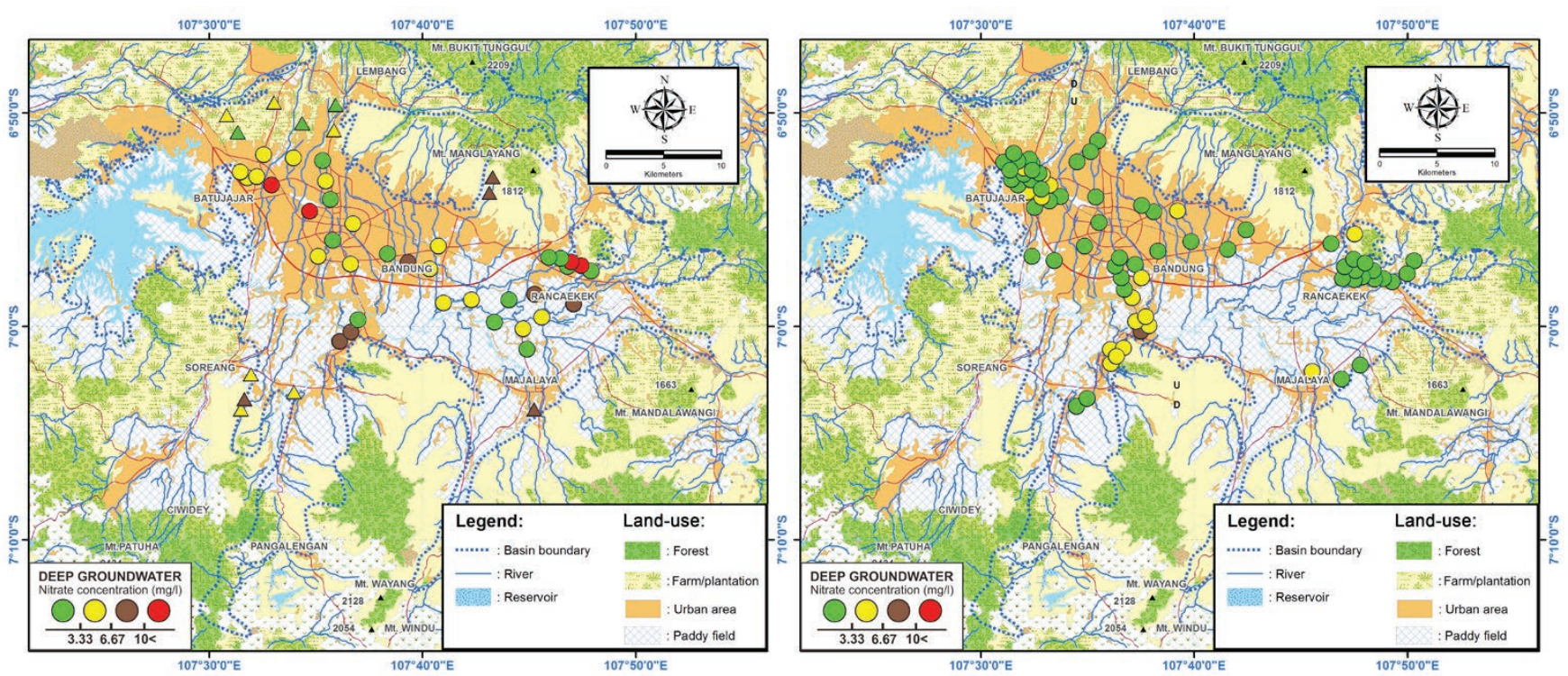

Figure 4. Distribution maps of nitrate concentrations for (a) shallow groundwater and (b) deep groundwater plotted on a land use map (BAKORSORTANAL, 2009). 


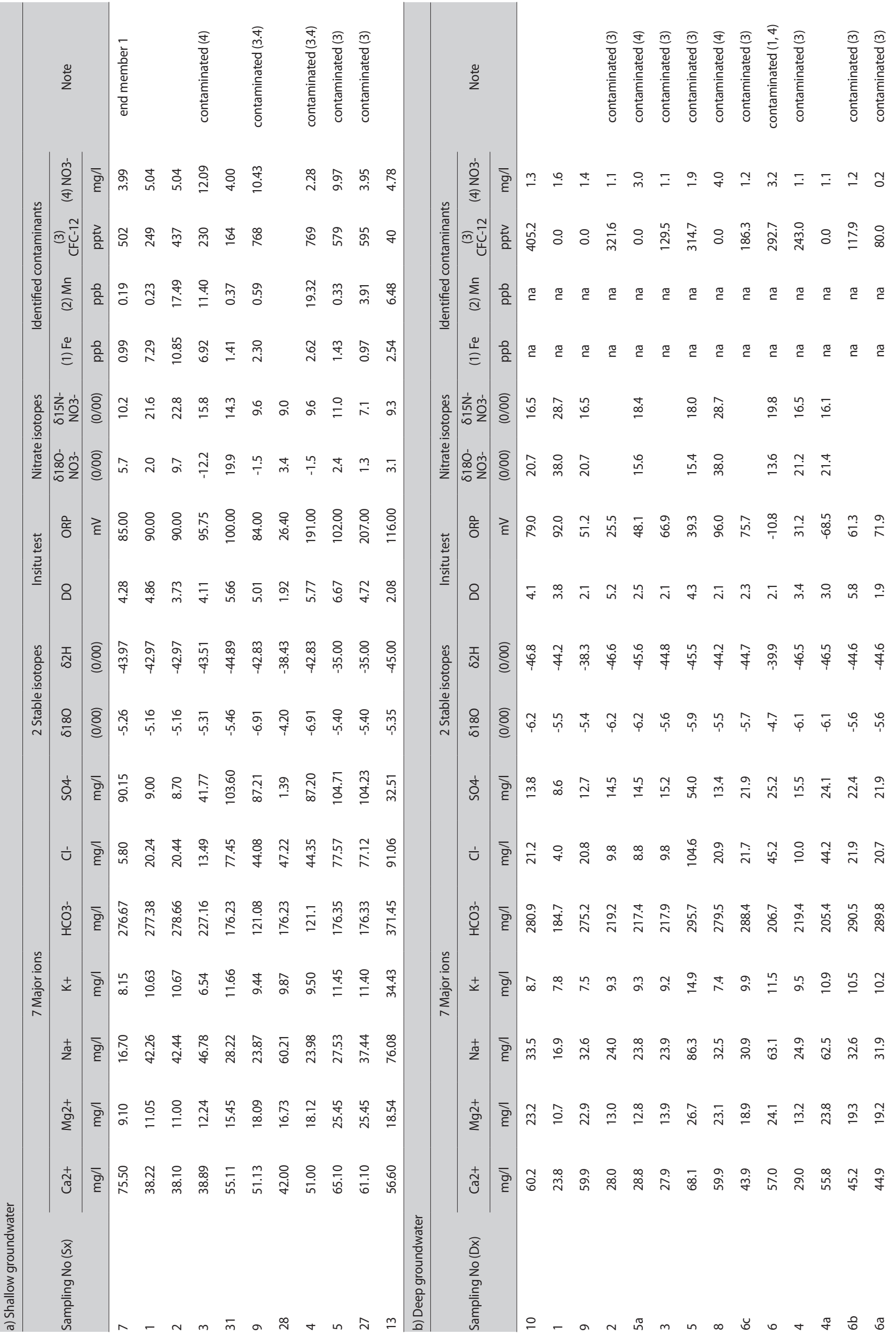




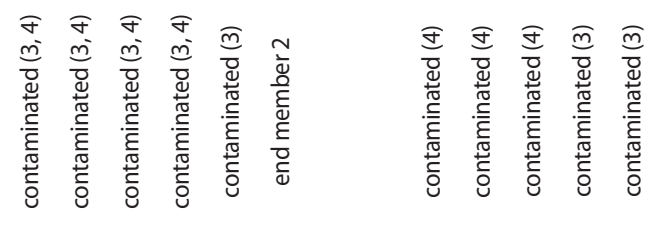

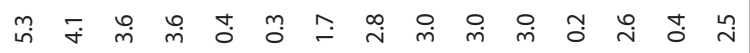

ํํㅇ

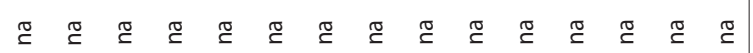

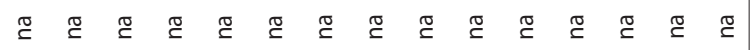

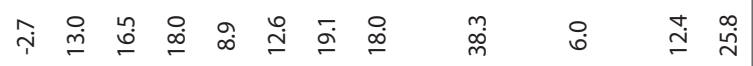

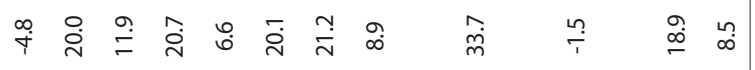

임

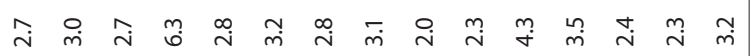

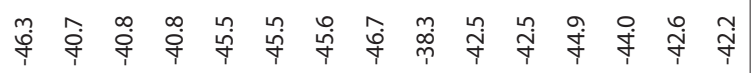

-

\்

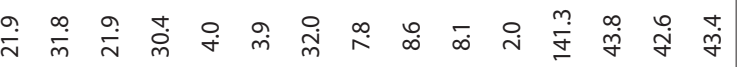

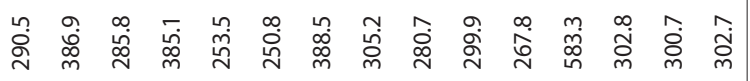

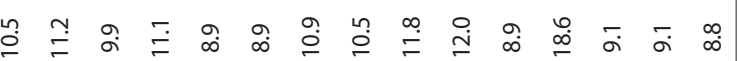

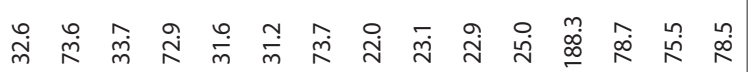

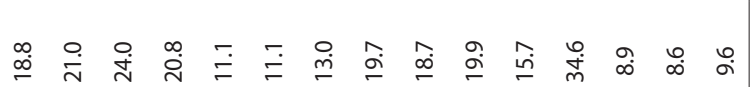

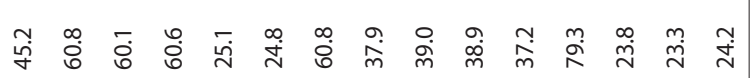

ปคํำ
Table 2. Summary of the statistical analysis from the calculated mixing ratios.

\begin{tabular}{|c|c|c|c|c|}
\hline \multicolumn{5}{|l|}{ a) $\mathrm{CMHI}$ area } \\
\hline Descriptive statistic & $\begin{array}{c}\text { CFC-12 } \\
\text { concentration*) }\end{array}$ & $\begin{array}{l}\text { Vertical } \\
\text { flux*) }\end{array}$ & $\begin{array}{l}\text { Total mixing } \\
\text { ratio }\end{array}$ & $\begin{array}{c}\text { Nitrate } \\
\text { mixing ratio }\end{array}$ \\
\hline Mean & 188.24 & 169,544 & 0.43 & 0.29 \\
\hline Standard Error & 26.48 & 20,299 & 0.05 & 0.10 \\
\hline Median & 156.17 & 178,186 & 0.49 & 0.26 \\
\hline Standard Deviation & 105.91 & 81,195 & 0.19 & 0.26 \\
\hline Range & 382.04 & 296,752 & 0.68 & 0.78 \\
\hline Minimum & 23.20 & 4,008 & 0.01 & 0.00 \\
\hline Maximum & 405.24 & 300,760 & 0.69 & 0.78 \\
\hline $\mathrm{n}$ & 16 & 16 & 16 & 7 \\
\hline \multicolumn{5}{|l|}{ b) RCK area } \\
\hline Mean & 114.80 & 201,819 & 0.15 & 0.29 \\
\hline Standard Error & 25.72 & 41,518 & 0.03 & 0.11 \\
\hline Median & 100.34 & 235,762 & 0.12 & 0.13 \\
\hline Standard Deviation & 92.72 & 155,347 & 0.10 & 0.30 \\
\hline Range & 290.34 & 464,918 & 0.27 & 0.77 \\
\hline Minimum & 11.72 & 11,262 & 0.00 & 0.02 \\
\hline Maximum & 302.06 & 476,180 & 0.27 & 0.79 \\
\hline $\mathrm{n}$ & 13 & 15 & 15 & 7 \\
\hline \multicolumn{5}{|l|}{ c) DHYK area } \\
\hline Mean & 211.29 & 161,058 & 0.12 & 0.29 \\
\hline Standard Error & 41.63 & 91,076 & 0.04 & 0.12 \\
\hline Median & 247.21 & 29,543 & 0.04 & 0.19 \\
\hline Standard Deviation & 117.74 & 340,774 & 0.16 & 0.29 \\
\hline Range & 346.06 & $1,303,381$ & 0.46 & 0.70 \\
\hline Minimum & 17.73 & 101 & 0.00 & 0.00 \\
\hline Maximum & 363.78 & $1,303,482$ & 0.46 & 0.70 \\
\hline $\mathrm{n}$ & 8 & 14 & 14 & 6 \\
\hline
\end{tabular}

The nitrogen isotope ratios of the possible source materials revealed unique signatures with some compositional variations. The $\delta^{15} \mathrm{~N}_{\mathrm{NO} 3}$ of groundwater samples ranged from $-1.2 \%$ to $47 \%$, and $\delta^{18} \mathrm{O}_{\mathrm{NO} 3}$ ranged from $-12.2 \%$ to $33.7 \%$ o. Differences in isotopic composition between the shallow and deep groundwater were not discovered, possibly due to the most likely and predominant source of nitrate contamination in the investigated areas being septic waste leakage (Group C) from the urban area.

For the purpose of this research to investigate groundwater mixing in the study areas, only nitrate concentrations in the three cone-of-depression areas were focused on. Notably, only deep groundwater containing CFC-12 concentrations were selected which implies either that it was recharged from shallow (younger) groundwater (TAUFIQ et al., 2017) or that the nitrate was also possibly recharged from the shallow groundwater. According to KENDALL (1998) and SINGLETON et al. (2007) the nitrate in these areas can be identified from the following potential source groups: A (3 samples), B (13 samples), C (34 samples), and D (5 samples), presented in Appendix 3 and Figure 5. In addition, deep groundwater samples with low DO values $(<2 \mathrm{mg} / \mathrm{l})$ were omitted because of the significant denitrification that preferentially occurs (BÖHLKE et al., 2002). The deep groundwater samples in the depression cone areas appeared to have been recharged from shallow groundwater that contained septic tank waste and/ or manure waste (Group C, as mentioned in Section 3.2), so only these samples in Group $\mathrm{C}$ were used to determine the nitrate mixing ratios. 
a)
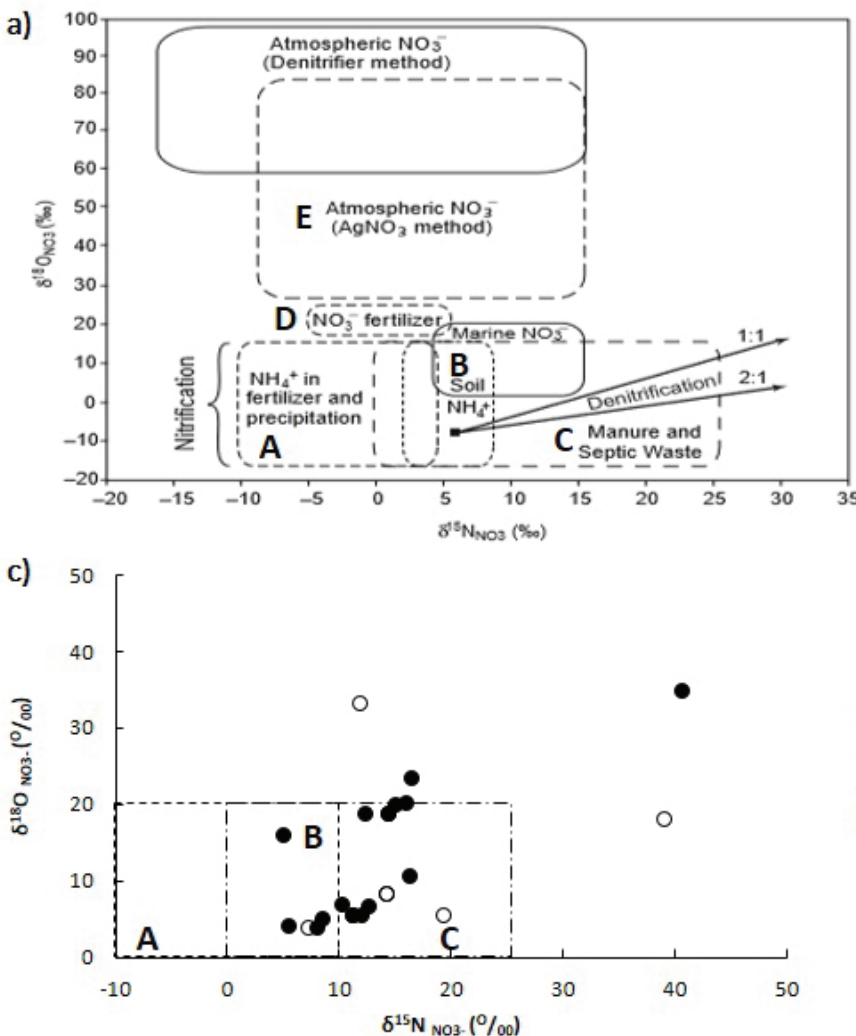
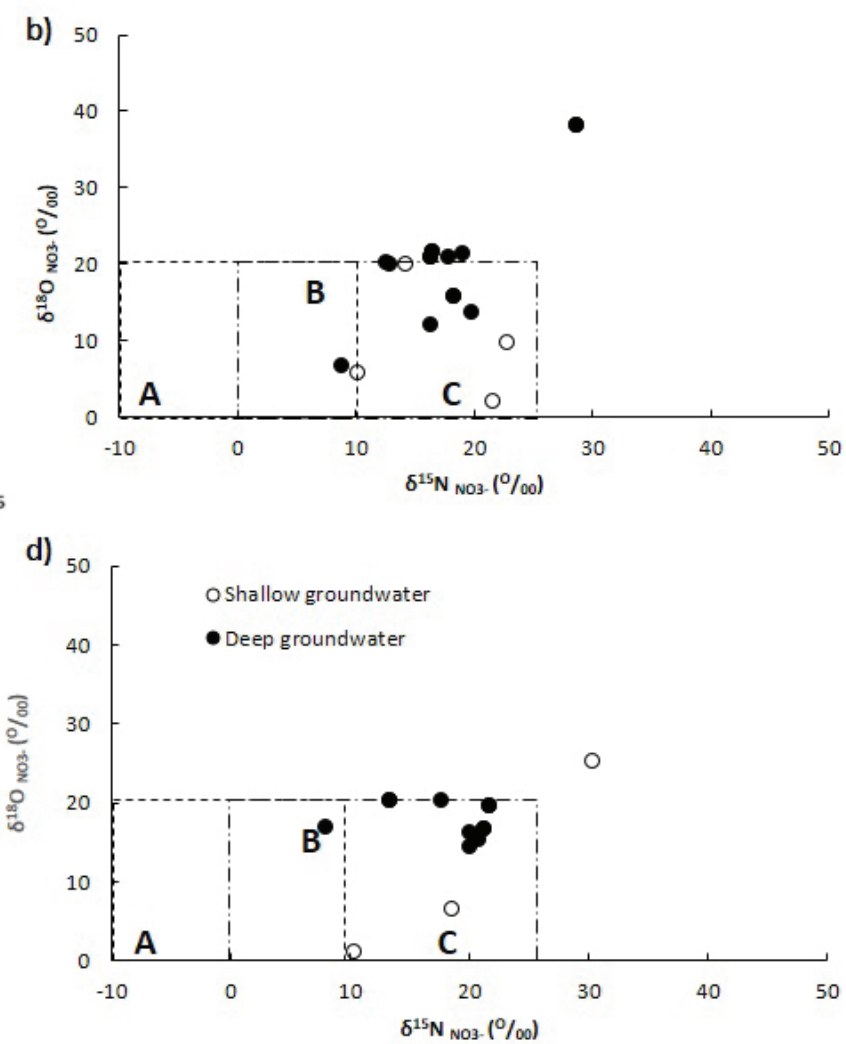

Figure 5. Nitrate isotope comparison with possible source groups according to (a) the method of KENDALL (1998) for groundwater samples of (b) the CMHI, (c) the RCK and (d) the DHYK areas.

The nitrate mixing ratios were calculated using only equation (1) with the same end-members as the total mixing ratio calculation (Section 4.2). The calculated nitrate mixing ratios were between 0.01 and 0.78 . The calculated mixing ratios for nitrate indicate that the mixing between the shallow and the deep groundwater clearly occurs in all three depression areas, but with different ratios. Both the differences in nitrate mixing ratios and total mixing ratios reflect the variation in magnitude of the flux from shallower to deeper groundwaters and are controlled by the degree of drawdown from pumping. The results are presented in Appendix 3., plotted in Figure 3b. and summarized in Table 2.

\section{DISCUSSION}

For further evaluation of groundwater mixing between the shallow and deep groundwaters caused by excessive pumping, the

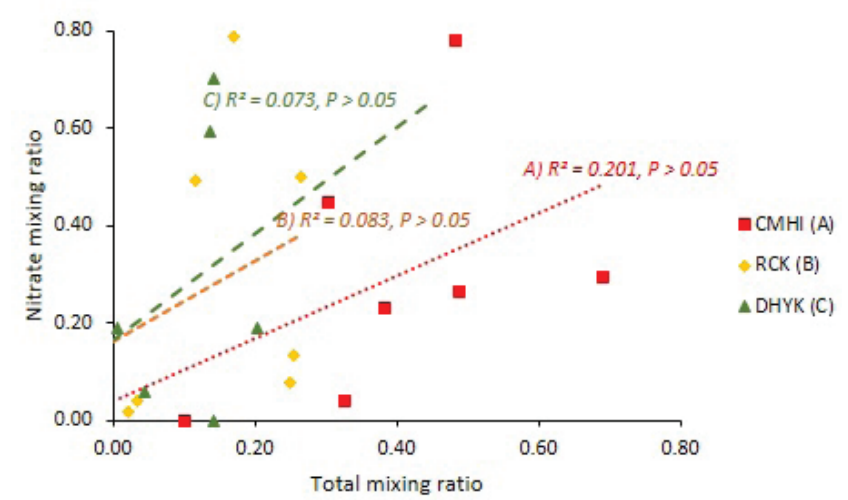

Figure 6. Correlation between the total mixing ratio and the nitrate mixing ratio for the three depression areas. Varicolored dashed lines indicate the regression line of each correlation for each area. calculated total mixing ratios were compared with other earlier results of TAUFIQ et al. (2018a). The first discussion involves the relationship between the total mixing ratio with 2 previous methods: between the magnitude of CFC-12 concentrations, when it is used as a hydrogeochemical tracer and the magnitude of vertical flux as determined by modeling (Table 2; TAUFIQ et al., 2017). The last discussion involves a comparison of calculation of mixing ratios using all the parameters against using only one parameter.

The total mixing ratios had a positive significant correlation $(\mathrm{p}<0.05, \mathrm{~N}=14)$ with the magnitude of vertical flux (Figure $3 \mathrm{a}$ ) as determined by modeling in all of the three depression areas, but there was a lower positive significant correlation with the magnitude of CFC-12 concentrations ( $p>0.05, \mathrm{~N}=14$ ) (Figure $3 b)$. They had different coefficients of correlation for each depression area. Remarkably, the highest significant correlation was found between the correlation of the total mixing ratio and magnitude of vertical flux in the CMHI area $(\mathrm{r}=0.81, \mathrm{p}<0.01, \mathrm{~N}=16)$. The CMHI area, with the largest groundwater drawdown, had the highest mean total mixing ratio, CFC-12 concentrations and vertical flux. The other two areas followed a similar pattern but with a lower mean value. This indicates that the method of the total mixing ratio is as effective as the two other methods, the hydrogeochemical tracer and the modeling, in revealing groundwater mixing.

The two methods of calculating mixing ratio were compared to show the relationship between using all parameters with using only one selected parameter. The comparison of calculating mixing ratio by using all parameters and by using only nitrate (Figure 6) shows a positive correlation ( $p>0.05, \mathrm{~N}=6)$. The CMHI area had the largest total mixing ratio and also the largest nitrate mixing ratio with the highest coefficient of correlation $(r=0.36$, 
$p>0.05, N=7$ ). The same positive correlation was found in all other areas, the RCK and the DHYK areas, but with lower correlation coefficients. Nitrate mixing ratios had a larger standard error ( $\mathrm{se}=0.10-0.12)$ than the total mixing ratios $(\mathrm{se}=0.03-0.05)$ for all depression areas (Table 2). The total mixing ratio shows a better fit in correlation with physical parameters than the nitrate mixing ratio does, suggesting that nitrate is ineffective as a prevailing contaminant tracer in this basin. It might be because nitrate in deep groundwater were controlled by many factors. Therefore, these results corroborate the findings of previous work (RUEEDI et al., 2005) which shows that estimations using all parameters could reduce the uncertainty.

\section{CONCLUSIONS}

The two methods for calculating mixing ratios were: (1) using all the parameters and (2) using only nitrate, presented for three depression areas in the Bandung basin which have different magnitudes of groundwater drawdown (the CMHI, RCK, and DHYK areas). The values for total mixing ratios indicate that mixing between the shallow and deep groundwaters clearly occurs in all three depression areas, but with different ratios. This means that the mixing processes from shallower to deeper groundwater occurred in areas with different ratios according to the major compositions. The area with the largest drawdown had the biggest value of the total mixing ratio. In addition, the spatial distribution map of total mixing ratios clearly shows that the largest ratio occurs near the centre of the cone of depression, and decreases gradually outwards away from the centre.

A positive correlation was found between total mixing ratios, CFC-12 concentrations, and the magnitude of vertical flux. This correlation indicates that estimating the total mixing ratio is as effective as using CFC-12 concentrations and vertical flux modeling for revealing groundwater mixing caused by the shallow groundwater that recharges the deep groundwater. Remarkably, the highest significant correlation is found between the correlation of the total mixing ratio and magnitude of vertical flux in the $\mathrm{CMHI}$ area. A comparison of calculating the mixing ratio using all the parameters and using nitrate only showed a less positive correlation thus nitrate is an ineffective tracer for prevailing contaminants for deep groundwaters in this basin. The nitrate mixing ratio also has a larger standard error than the result of total mixing ratio, therefore these results show that estimations using all parameters could reduce the uncertainty. Overall, this study concludes that the method of total mixing ratio using all chemical parameters is the most effective, can reduce the uncertainty and is consistent with the method using physical parameters.

\section{ACKNOWLEDGEMENT}

We would like to express gratitude to emeritus Professor Dr. Jun SHIMADA (Kumamoto University) for valuable suggestions and discussion.

\section{REFERENCES}

BAKORSOTANAL (2009): Land use map, sub Bandung region, scale 1: 50.000. Agency of geospatial information: Republic of Indonesia.

BEYERLE, U., AESCHBA, C.H., HERTIG, W., HOFER, M., IMBODEN, D.M., BAUR, H. \& KIPFER, R. (1999): Infiltration of river water to a shallow aquifer investigated with $3 \mathrm{H} / 3 \mathrm{He}$, noble gases and CFCs.- Journal of Hydrology, 220, $169-185$.

BÖHLKE, J.K., WANTY, R., TUTTLE, M., DELIN, G. \& LANDON, M. (2002): Denitrification in the recharge area and discharge area of a transient agricultural nitrate plume in a glacial outwash sand aquifer, Minnesota.- Water Resource Research, 38, 10-26.
BURNETT, W.C, PETERSON, R.N, SANTOS, I.R. \& HICKS, R.W. (2010): Use of automated radon measurements for rapid assessment of groundwater flow into Florida streams.- Journal of Hydrology, 380, Issues 3-4, 298-304. doi: 10.1016/j. jhydrol.2009.11.005

CASCIOTTI, K.L., SIGMAN, D.M., GALANTER H.M., BÖHLKE, J.K. \& HILKERT, A. (2002): Measurement of the oxygen isotopic composition of nitrate in seawater and freshwater using the denitrifier method.-Analytical Chemistry, 74, 4905-4912.

FOSTER, S.S.D. \& CHILTON, P.J. (2003): Groundwater: the process and global significance of aquifer degradation. Philosophical Transactions of the Royal Society of London.- Biological Sciences, 358, 1957-1972.

HAN, D.H., LIANG, X., JIN, M.G., CURRELL, M.J., SONG, X.F. \& LIU, C.M (2010): Evaluation of groundwater hydrochemical characteristics and mixing behavior in the Daying and Qicun geothermal systems, Xinzhou Basin.- Journal of Volcanology and Geothermal Research, 189, 92-104. doi: 10.1016/j.jvolgeores.2009.10.011

HOSONO, T., DELINOM, R., NAKANO, T., KAGABU, M., \& SHIMADA, J. (2011): Evolution model of $\delta^{34} \mathrm{~S}$ and $\delta^{18} \mathrm{O}$ in dissolved sulfate in volcanic fan aquifers from recharge to coastal zone and through the Jakarta urban area, Indonesia.- Science of the Total Environment, 409, 2541-2554.

HOSONO, T., TOKUNAGA, T., KAGABU, M., NAKATA, H., ORISHIKIDA, T., LIN, I. \& SHIMADA, J (2013): The use of $\delta^{15} \mathrm{~N}$ and $\delta^{18} \mathrm{O}$ tracers with an understanding of groundwater flow dynamics for evaluating the origins and attenuation mechanisms of nitrate pollution.- Water Research, 47, 2661-2675.

HOSONO, T., TOKUNAGA, T., TSUSHIMAA, A. \& SHIMADA, J. (2014): Combined use of $\delta^{13} \mathrm{C}, \delta^{15} \mathrm{~N}$, and $\delta^{34} \mathrm{~S}$ tracers to study anaerobic bacterial processes in groundwater flow systems.- Water Research, 54, 284-296.

HUTASOIT, L.M. (2009): Groundwater condition of Bandung area, with and without artificial recharge: Numerical simulation results.- Indonesian Journal on Geoscience, 4, 1777-188 (In Indonesian).

JAGO-ON, K.A.B., KANEKO, S., FUJIKURA, R., FUJIWARA, A., IMAI, T., MATSUMOTO, T., ZHANG, J., TANIKAWA, H., TANAKA, K,, LEE, B., \& TANIGUCHI M. (2009): Urbanization and subsurface environmental issues: an attempt at DPSIR model application in Asian cities.- Science of the Total Environment, 407, 308-310. doi: 10.1016/j.scitotenv.2008.08.004

KAPLAN, N. \& MAGARITZ, M. (1986): A nitrogen-isotope study of the sources of nitrate contamination in groundwater of the Pleistocene coastal plain aquifer, Israel.- Water Research, 20, 131-135. doi: 10.1016/0043-1354(86)90002-3

KENDALL, C. (1998): Tracing nitrogen sources and cycling in catchments.- In: KENDALL, C. \& McDONNELL, J.J. (eds.): Isotope Tracers in Catchment Hydrology. Elsevier. Science B.V., Amsterdam, 519-576. doi: 10.1016/B978-0-444-815460.50023-9

KREITLER, C.W. (1979): Nitrogen-isotope ratio studies of soils and groundwater nitrate from alluvial fan aquifers in Texas.- Journal of Hydrology, 42, 147-170.

RUEEDI, J., PURTSCHERT, R., BEYERLE, U., ALBERICH, C. \& KIPFER, R. (2005): Estimating groundwater mixing ratios and their uncertainties using a statistical multi parameter approach.- Journal of Hydrology, 305, 1-14. doi: 10.1016/j.jhydrol.2004.06.044

SIGMAN, D.M., CASCIOTTI, K.L., ANDREANI, M., BARFORD, C., GALANTER, M. \& BÖHLKE, J.K. (2001): A bacterial method for the nitrogen isotopic analysis of nitrate in seawater and freshwater-- Analytical Chemistry, 73, 145-153. doi: 10.1021/ac010088e

SINGLETON, M.J., ESSER, B.K., MORAN, J.E., HUDSON, G.B., MCNAB, W.W. \& HARTER, T. (2007): Saturated zone denitrification: potential for natural attenuation of nitrate contamination in shallow groundwater under dairy operations.- Environmental Science and Technology, 41, 759-765. doi: 10.1021/es061253g

TANIGUCHI, M., SHIMADA, J., FUKUDA, Y., YAMANO, M., ONODERA, S., KANEKO, S. \& YOSHIKOSHI, A. (2009): Anthropogenic effects on the subsurface thermal and groundwater environments in Osaka, Japan and Bangkok, Thailand.- Science of the Total Environment, 407, 3153-3164. doi: 10.1016/j.scitotenv.2008.06.064

TAUFIQ, A., HOSONO, T., IDE, K., KAGABU M., ISKANDAR, I., EFFENDI A.J., HUTASOIT, L.M. \& SHIMADA, J. (2017): Impact of excessive groundwater pumping on rejuvenation age processes in the Bandung basin, Indonesia as determined by hydrogeochemistry and modeling.- Hydrogeology Journal, 26, 12631279. doi: 10.1007/s10040-017-1696-8

TAUFIQ, A., EFFENDI, A.J., ISKANDAR, I., HOSONO, T. \& HUTASOIT, L.M. (2018): Controlling Factors and Driving Mechanisms Nitrate Contamination in Groundwater System of Bandung Basin, Indonesia, deduced by combined use of stable isotope ratios, CFC age dating, and socioeconomic parameters.- Water Research Journal. https://doi.org/10.1016/j.watres.2018.10.049 (article in press).

WAGNER, W. \& SUKRISNO, X. (1998): Natural groundwater quality and groundwater contamination in the Bandung basin, Indonesia.- Indonesia Bulletin of Environmental geology, 23.

WIRAKUSUMAH, A.D. \& DANARYANTO, H. (2004): Groundwater management in Indonesia Case Study: Groundwater conservation in Jakarta, Bandung and Semarang. 41st Coordinating Committee for Geoscience Programmes in East and Southeast Asia (CCOP) (Tsukuba, Japan). 
Appendix 1. Data of all parameters for shallow and deep groundwater with their identified elevated substances

a) Shallow groundwate

\begin{tabular}{|c|c|c|c|c|c|c|c|c|c|c|c|c|c|c|c|c|c|c|}
\hline \multirow[b]{2}{*}{$\begin{array}{l}\text { Sampling No } \\
\text { (Sx) }\end{array}$} & \multicolumn{7}{|c|}{7 Major ions } & \multicolumn{2}{|c|}{2 Stable isotopes } & \multicolumn{2}{|c|}{ Insitu test } & \multicolumn{2}{|c|}{ Nitrate isotopes } & \multicolumn{4}{|c|}{ Elevated substances } & \multirow[b]{2}{*}{ Note } \\
\hline & $\begin{array}{l}\mathrm{Ca}^{2+} \\
\mathrm{mg} / 1\end{array}$ & $\begin{array}{c}\mathrm{Mg}^{2+} \\
\mathrm{mg} / 1\end{array}$ & $\begin{array}{l}\mathrm{Na}^{+} \\
\mathrm{mg} / \mathrm{l}\end{array}$ & $\begin{array}{c}\mathrm{K}^{+} \\
\mathrm{mg} / 1\end{array}$ & $\begin{array}{c}\mathrm{HCO}_{3}{ }^{-} \\
\mathrm{mg} / \mathrm{l}\end{array}$ & $\begin{array}{c}\mathrm{Cl} \\
\mathrm{mg} / 1\end{array}$ & $\begin{array}{l}\mathrm{SO}_{4}^{-} \\
\mathrm{mg} / \mathrm{l}\end{array}$ & $\begin{array}{l}\delta^{18} \mathrm{O} \\
(\% 0)\end{array}$ & $\begin{array}{l}\delta^{2} \mathrm{H} \\
(\% 00)\end{array}$ & DO & $\begin{array}{c}\text { ORP } \\
\mathrm{mV}\end{array}$ & $\begin{array}{c}\delta^{18} \mathrm{O}_{\mathrm{NO}} \\
(\%)\end{array}$ & $\begin{array}{c}\delta^{15} \mathrm{~N}_{\mathrm{NO}} \\
\left(\%{ }_{00}\right)\end{array}$ & $\begin{array}{l}\text { (1) } \mathrm{Fe} \\
\mathrm{ppb}\end{array}$ & $\begin{array}{c}\text { (2) } \mathrm{Mn} \\
\mathrm{ppb}\end{array}$ & $\begin{array}{l}\text { (3) } \mathrm{CFC} \\
\mathrm{pptv}\end{array}$ & $\begin{array}{l}\text { (4) } \mathrm{NO}_{3}{ }^{-} \\
\mathrm{mg} / 1\end{array}$ & \\
\hline 7 & 75.50 & 9.10 & 16.70 & 8.15 & 276.67 & 5.80 & 90.15 & -5.26 & -43.97 & 4.28 & 85.00 & 5.7 & 10.2 & 0.99 & 0.19 & 502 & 3.99 & end member 1 \\
\hline 2 & 38.10 & 11.00 & 42.44 & 10.67 & 278.66 & 20.44 & 8.70 & -5.16 & -42.97 & 3.73 & 90.00 & 9.7 & 22.8 & 10.85 & 17.49 & 437 & 5.04 & contaminated (4) \\
\hline 3 & 38.89 & 12.24 & 46.78 & 6.54 & 227.16 & 13.49 & 41.77 & -5.31 & -43.51 & 4.11 & 95.75 & -12.2 & 15.8 & 6.92 & 11.40 & 230 & 12.09 & contaminated (4) \\
\hline 31 & 55.11 & 15.45 & 28.22 & 11.66 & 176.23 & 77.45 & 103.60 & -5.46 & -44.89 & 5.66 & 100.00 & 19.9 & 14.3 & 1.41 & 0.37 & 164 & 4.00 & contaminated (4) \\
\hline 9 & 51.13 & 18.09 & 23.87 & 9.44 & 121.08 & 44.08 & 87.21 & -6.91 & -42.83 & 5.01 & 84.00 & -1.5 & 9.6 & 2.30 & 0.59 & 768 & 10.43 & contaminated (3.4) \\
\hline 28 & 42.00 & 16.73 & 60.21 & 9.87 & 176.23 & 47.22 & 1.39 & -4.20 & -38.43 & 1.92 & 26.40 & 3.4 & 9.0 & & & & & \\
\hline 4 & 51.00 & 18.12 & 23.98 & 9.50 & 121.1 & 44.35 & 87.20 & -6.91 & -42.83 & 5.77 & 191.00 & -1.5 & 9.6 & 2.62 & 19.32 & 769 & 2.28 & contaminated (3) \\
\hline 5 & 65.10 & 25.45 & 27.53 & 11.45 & 176.35 & 77.57 & 104.71 & -5.40 & -35.00 & 6.67 & 102.00 & 2.4 & 11.0 & 1.43 & 0.33 & 579 & 9.97 & contaminated (3) \\
\hline 27 & 61.10 & 25.45 & 37.44 & 11.40 & 176.33 & 77.12 & 104.23 & -5.40 & -35.00 & 4.72 & 207.00 & 1.3 & 7.1 & 0.97 & 3.91 & 595 & 3.95 & contaminated (3) \\
\hline 13 & 56.60 & 18.54 & 76.08 & 34.43 & 371.45 & 91.06 & 32.51 & -5.35 & -45.00 & 2.08 & 116.00 & 3.1 & 9.3 & 2.54 & 6.48 & 40 & 4.78 & ontaminated (4) \\
\hline
\end{tabular}

\begin{tabular}{|c|c|c|c|c|c|c|c|c|c|c|c|c|c|c|c|c|c|c|}
\hline \multirow[b]{2}{*}{$\begin{array}{l}\text { Sampling No } \\
\text { (Sx) }\end{array}$} & \multicolumn{7}{|c|}{7 Major ions } & \multicolumn{2}{|c|}{2 Stable isotopes } & \multicolumn{2}{|c|}{ Insitu test } & \multicolumn{2}{|c|}{ Nitrate isotopes } & \multicolumn{4}{|c|}{ Elevated substances } & \multirow[b]{2}{*}{ Note } \\
\hline & $\begin{array}{l}\mathrm{Ca}^{2+} \\
\mathrm{mg} / 1\end{array}$ & $\begin{array}{c}\mathrm{Mg}^{2+} \\
\mathrm{mg} / 1\end{array}$ & $\begin{array}{l}\mathrm{Na}^{+} \\
\mathrm{mg} / 1\end{array}$ & $\begin{array}{c}\mathrm{K}^{+} \\
\mathrm{mg} / 1\end{array}$ & $\begin{array}{c}\mathrm{HCO}_{3}^{-} \\
\mathrm{mg} / 1\end{array}$ & $\begin{array}{c}\mathrm{Cl} \\
\mathrm{mg} / 1\end{array}$ & $\begin{array}{l}\mathrm{SO}_{4}^{-} \\
\mathrm{mg} / 1\end{array}$ & $\begin{array}{l}\delta^{18} \mathrm{O} \\
\left(\%{ }_{00}\right)\end{array}$ & $\begin{array}{l}\delta^{2} \mathrm{H} \\
\left(\%{ }_{00}\right)\end{array}$ & DO & $\begin{array}{c}\text { ORP } \\
\mathrm{mV}\end{array}$ & $\begin{array}{c}\delta^{18} \mathrm{O}_{\mathrm{NO} 3} \\
\left(\%{ }_{00}\right)\end{array}$ & $\begin{array}{c}\delta^{15} \mathrm{~N}_{\mathrm{NO}} \\
(\% \% 0)\end{array}$ & $\begin{array}{l}\text { (1) } \mathrm{Fe} \\
\mathrm{ppb}\end{array}$ & $\begin{array}{l}\text { (2) } \mathrm{Mn} \\
\mathrm{ppb}\end{array}$ & $\begin{array}{c}\text { (3) CFC- } \\
\text { pptv }\end{array}$ & $\begin{array}{c}\text { 2 (4) } \mathrm{NO}_{3}^{-} \\
\mathrm{mg} / \mathrm{l}\end{array}$ & \\
\hline $30 \mathrm{a}$ & 55.52 & 14.47 & 48.05 & 13.50 & 310.20 & 16.80 & 29.21 & -6.23 & -48.49 & 4.70 & 99.51 & 8.1 & 14.4 & 63.60 & 1.49 & 21 & 1.08 & \\
\hline 30 & 55.57 & 14.85 & 48.38 & 13.63 & 310.86 & 16.75 & 29.16 & -6.22 & -48.47 & 3.97 & 147.79 & & & 3.37 & 1.69 & & 20.69 & contaminated (4) \\
\hline 29 & 53.43 & 17.59 & 61.67 & 8.93 & 283.96 & 33.79 & 34.60 & -5.01 & -43.21 & 3.21 & 132.74 & 17.9 & 39.1 & 1.15 & 1.68 & & 7.62 & contaminated (4) \\
\hline 26 & 53.99 & 17.60 & 58.06 & 8.80 & 283.76 & 33.50 & 34.66 & -4.88 & -41.84 & 0.00 & & 3.6 & 7.3 & 0.40 & 0.23 & & 1.06 & \\
\hline 20 & 55.52 & 14.47 & 48.05 & 13.50 & 310.20 & 16.80 & 29.21 & -6.22 & -48.47 & 3.71 & 173.00 & 8.1 & 14.4 & 3.65 & 26.37 & 21 & 1.08 & \\
\hline 24 & 53.90 & 17.60 & 61.06 & 8.90 & 283.80 & 33.42 & 34.45 & -5.53 & -47.98 & 4.24 & 174.00 & 5.2 & 19.5 & 0.00 & 0.09 & 12 & 1.97 & \\
\hline $21 \mathrm{a}$ & 19.60 & 10.98 & 60.10 & 5.75 & 251.89 & 52.30 & 1.84 & -4.87 & -41.83 & 6.61 & 90.00 & 15.0 & 12.1 & 6.79 & & 58 & 1.25 & \\
\hline 23 & 58.20 & 22.80 & 69.70 & 16.40 & 385.80 & 91.20 & 18.90 & -3.94 & -41.48 & 2.47 & 87.00 & 18.2 & 47.0 & 1.04 & 4.67 & 56 & 1.65 & \\
\hline 16 & 61.20 & 19.71 & 89.39 & 27.20 & 423.13 & 111.29 & 24.52 & -4.92 & -41.46 & 4.16 & 107.00 & 15.4 & 21.0 & 70.79 & 9.52 & 85 & 5.75 & contaminated (4) \\
\hline 13 & 56.60 & 18.54 & 76.08 & 34.43 & 371.45 & 91.06 & 32.51 & -5.35 & -45.00 & 2.08 & 116.00 & 3.1 & 9.3 & 2.54 & 6.48 & 40 & 4.78 & contaminated (4) \\
\hline
\end{tabular}

\begin{tabular}{|c|c|c|c|c|c|c|c|c|c|c|c|c|c|c|c|c|c|c|}
\hline \multicolumn{19}{|l|}{$3 \mathrm{DHYK}$ area } \\
\hline \multirow{2}{*}{$\begin{array}{l}\text { Sampling No } \\
\text { (Sx) }\end{array}$} & \multicolumn{7}{|c|}{7 Major ions } & \multicolumn{2}{|c|}{2 Stable isotopes } & \multicolumn{2}{|c|}{ Insitu test } & \multicolumn{2}{|c|}{ Nitrate isotopes } & \multicolumn{4}{|c|}{ Elevated substances } & \multirow[b]{2}{*}{ Note } \\
\hline & $\begin{array}{l}\mathrm{Ca}^{2+} \\
\mathrm{mg} / 1\end{array}$ & $\begin{array}{c}\mathrm{Mg}^{2+} \\
\mathrm{mg} / \mathrm{l}\end{array}$ & $\begin{array}{l}\mathrm{Na}^{+} \\
\mathrm{mg} / 1\end{array}$ & $\begin{array}{c}\mathrm{K}^{+} \\
\mathrm{mg} / 1\end{array}$ & $\begin{array}{c}\mathrm{HCO}_{3}^{-} \\
\mathrm{mg} / 1\end{array}$ & $\begin{array}{c}\mathrm{Cl} \\
\mathrm{mg} / 1\end{array}$ & $\begin{array}{l}\mathrm{SO}_{4}{ }^{-} \\
\mathrm{mg} / 1\end{array}$ & $\begin{array}{l}\delta^{18} \mathrm{O} \\
\left(\%{ }_{00}\right)\end{array}$ & $\begin{array}{l}\delta^{2} \mathrm{H} \\
(\% 0)\end{array}$ & DO & $\begin{array}{c}\text { ORP } \\
\mathrm{mV}\end{array}$ & $\begin{array}{c}\delta^{18} \mathrm{O}_{\mathrm{NO} 3} \\
\left(\%{ }_{00}\right)\end{array}$ & $\begin{array}{c}\delta^{15} \mathrm{~N}_{\mathrm{NO}} \\
(\% \% 0)\end{array}$ & $\begin{array}{l}\text { (1) } \mathrm{Fe} \\
\mathrm{ppb}\end{array}$ & $\begin{array}{l}\text { (2) } \mathrm{Mn} \\
\mathrm{ppb}\end{array}$ & $\begin{array}{l}\text { (3) } \mathrm{CFC}^{-1}- \\
\text { pptv }\end{array}$ & $\begin{array}{l}\text { 4) } \mathrm{NO}_{3}^{-} \\
\mathrm{mg} / 1\end{array}$ & \\
\hline $15 \mathrm{~d}$ & 45.17 & 18.75 & 31.91 & 10.21 & 290.50 & 20.90 & 21.80 & & & & 115 & 5.0 & 10.8 & 0.54 & 0.23 & 692.75 & 2.25 & contaminated (3) \\
\hline $6 a$ & 62.04 & 23.14 & 31.05 & 6.35 & 168.44 & 86.60 & 43.31 & -5.53 & -39.00 & 5.2 & 192 & 4.5 & 16.9 & 45.73 & 1.99 & 9.06 & 3.42 & contaminated (4) \\
\hline 9 & 51.13 & 18.09 & 23.87 & 9.44 & 121.08 & 44.08 & 87.21 & -5.91 & -42.83 & 5.0 & 84 & -1.5 & 9.6 & 2.30 & 0.59 & 767.92 & 10.43 & contaminated (3.4) \\
\hline 19 & 62.40 & 23.10 & 30.30 & 6.50 & 168.33 & 86.50 & 43.30 & -4.49 & -29.75 & 3.5 & 90 & 1.4 & -1.2 & 0.21 & 0.10 & 250.33 & 3.33 & contaminated (4) \\
\hline 28 & 42.00 & 16.73 & 60.21 & 9.87 & 176.23 & 47.22 & 1.39 & -4.20 & -38.43 & 1.9 & 26 & 3.4 & 9.0 & 699.41 & 532.13 & & 1.30 & contaminated (2) \\
\hline 18 & 55.01 & 15.34 & 29.11 & 11.41 & 176.98 & 77.30 & 104.60 & -5.30 & -44.07 & 3.5 & 125 & 5.5 & 12.9 & 0.01 & 0.64 & 1132.00 & 3.87 & contaminated $(3,4)$ \\
\hline 31 & 17.65 & 6.55 & 11.70 & 3.52 & 130.20 & 4.10 & 9.60 & -5.60 & -35.61 & 4.6 & 125 & & & 0.67 & 0.14 & 1276.19 & 3.00 & contaminated $(3,4)$ \\
\hline 10 & 76.64 & 9.17 & 16.99 & 8.18 & 280.69 & 6.00 & 90.10 & -6.17 & -46.77 & 4.0 & 68 & 25.2 & 30.5 & 0.72 & 1.62 & 646.69 & 1.67 & contaminated (3) \\
\hline 11 & 52.40 & 15.48 & 27.39 & 10.31 & 248.09 & 12.00 & 49.65 & -5.19 & -42.70 & 2.9 & 82 & 1.0 & 10.5 & 2.52 & 6.28 & 192.67 & 2.99 & end member 1 \\
\hline $11 \mathrm{a}$ & 52.50 & 15.45 & 27.10 & 10.31 & 247.89 & 11.00 & 49.50 & -5.19 & -42.70 & 1.8 & 162 & 6.4 & 18.7 & 18.36 & 144.18 & 646.69 & 9.02 & contaminated (3) \\
\hline
\end{tabular}

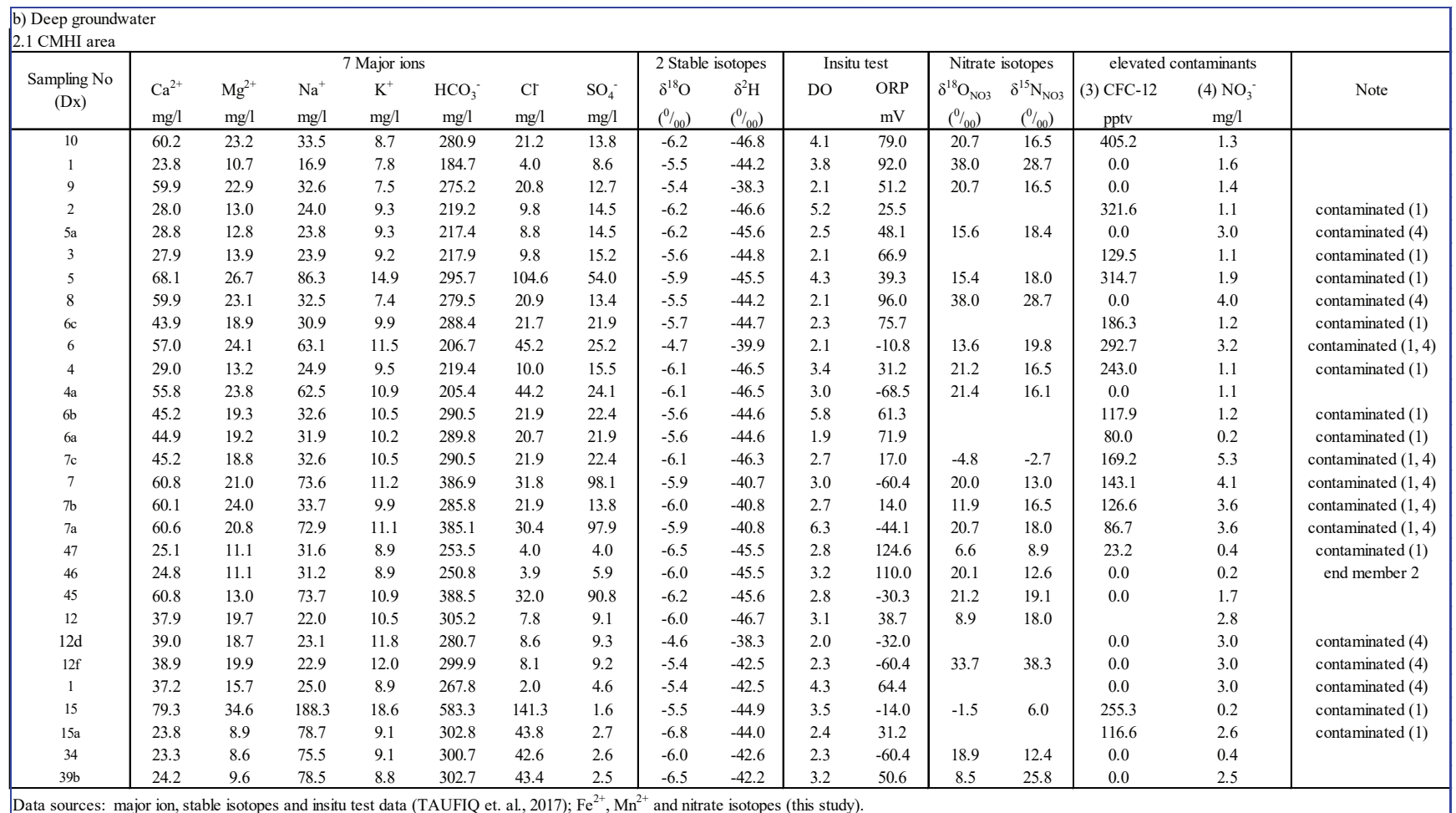

Data sources: major ion, stable isotopes and insitu test data (TAUFIQ et. al., 2017); $\mathrm{Fe}^{2+}, \mathrm{Mn}^{2+}$ and nitrate isotopes (this study). 
Appendix 1. Continuation.

\begin{tabular}{|c|c|c|c|c|c|c|c|c|c|c|c|c|c|c|c|c|}
\hline \multicolumn{17}{|l|}{$2.2 \mathrm{RCK}$ area } \\
\hline \multirow[b]{2}{*}{$\begin{array}{l}\text { Sampling No } \\
\text { (Dx) }\end{array}$} & \multicolumn{7}{|c|}{7 Major ions } & \multicolumn{2}{|c|}{2 Stable isotopes } & \multicolumn{2}{|c|}{ Insitu test } & \multicolumn{2}{|c|}{ Nitrate isotopes } & \multicolumn{2}{|c|}{ elevated contaminants } & \multirow[b]{2}{*}{ Note } \\
\hline & $\begin{array}{l}\mathrm{Ca}^{2+} \\
\mathrm{mg} / \mathrm{l}\end{array}$ & $\begin{array}{l}\mathrm{Mg}^{2+} \\
\mathrm{mg} / \mathrm{l}\end{array}$ & $\begin{array}{l}\mathrm{Na}^{+} \\
\mathrm{mg} / \mathrm{l}\end{array}$ & $\begin{array}{c}\mathrm{K}^{+} \\
\mathrm{mg} / \mathrm{l}\end{array}$ & $\begin{array}{c}\mathrm{HCO}_{3}{ }^{-} \\
\mathrm{mg} / \mathrm{l}\end{array}$ & $\begin{array}{c}\mathrm{Cl} \\
\mathrm{mg} / 1\end{array}$ & $\begin{array}{l}\mathrm{SO}_{4}{ }^{-} \\
\mathrm{mg} / \mathrm{l}\end{array}$ & $\begin{array}{l}\delta^{18} \mathrm{O} \\
\left(\%{ }_{00}\right)\end{array}$ & $\begin{array}{l}\delta^{2} \mathrm{H} \\
\left(\% \%_{00}\right)\end{array}$ & DO & $\begin{array}{c}\text { ORP } \\
\mathrm{mV}\end{array}$ & $\begin{array}{c}\delta^{18} \mathrm{O}_{\mathrm{NO} 3} \\
(\% \%)\end{array}$ & $\begin{array}{c}\delta^{15} \mathrm{~N}_{\mathrm{NO} 3} \\
(\% \%)\end{array}$ & $\begin{array}{c}\text { (3) } \mathrm{CFC}-12 \\
\text { pptv }\end{array}$ & $\begin{array}{l}\text { (4) } \mathrm{NO}_{3}{ }^{-} \\
\mathrm{mg} / \mathrm{l}\end{array}$ & \\
\hline 23 & 21.5 & 8.3 & 10.5 & 2.3 & 157.2 & 2.0 & 3.2 & -6.2 & -51.5 & 4.3 & 147.2 & 6.4 & 12.9 & & 3.2 & contaminated (4) \\
\hline $22 \mathrm{a}$ & 39.2 & 9.2 & 13.5 & 5.0 & 160.8 & 0.6 & 1.1 & -6.1 & -41.0 & 5.3 & 130.9 & 34.6 & 40.8 & 120.7 & 2.0 & contaminated (1) \\
\hline 22 & 39.9 & 7.4 & 6.9 & 3.0 & 110.6 & 2.7 & 0.5 & -6.3 & -50.8 & 5.6 & 124.0 & 5.4 & 12.2 & 302.1 & 4.0 & contaminated $(1,4)$ \\
\hline 21 & 39.2 & 9.3 & 13.6 & 5.0 & 170.4 & 0.7 & 1.2 & -6.3 & -51.1 & 5.3 & 171.0 & 3.6 & 8.2 & 100.3 & 2.1 & contaminated (1) \\
\hline $33 \mathrm{a}$ & 36.1 & 15.5 & 48.9 & 6.3 & 275.9 & 44.2 & 8.1 & -5.8 & -48.4 & 3.7 & 18.0 & 19.7 & 15.2 & 234.8 & 0.4 & contaminated (1) \\
\hline 25 & 36.3 & 14.9 & 48.2 & 6.5 & 280.1 & 44.1 & 8.7 & -6.0 & -48.9 & 5.5 & 134.6 & 3.8 & 5.7 & 238.4 & 0.5 & contaminated (1) \\
\hline 20 & 33.2 & 25.0 & 55.6 & 13.6 & 375.4 & 42.6 & 0.8 & -5.4 & -45.8 & 4.0 & 99.5 & 5.2 & 11.4 & 48.3 & 2.0 & contaminated (1) \\
\hline 24 & 25.2 & 14.1 & 16.8 & 7.1 & 233.1 & 1.3 & 6.4 & -6.1 & -48.8 & 3.2 & 132.7 & 4.7 & 8.7 & 11.7 & 0.5 & contaminated (1) \\
\hline $24 \mathrm{~b}$ & 25.2 & 14.1 & 16.1 & 7.1 & 230.2 & 1.2 & 6.3 & -5.4 & -45.8 & 4.0 & 159.0 & 5.2 & 11.4 & 105.7 & 0.2 & contaminated (1) \\
\hline $19 \mathrm{c}$ & 38.0 & 18.1 & 50.8 & 7.8 & 298.3 & 60.7 & 0.6 & -5.5 & -47.0 & 2.2 & 5.0 & 18.6 & 14.6 & 68.1 & 0.3 & contaminated (1) \\
\hline $18 \mathrm{a}$ & 46.5 & 19.2 & 110.5 & 9.1 & 375.4 & 121.7 & 2.7 & -4.5 & -42.8 & 4.4 & -6.0 & 19.8 & 16.2 & 27.9 & 0.2 & contaminated (1) \\
\hline 20a & 36.1 & 16.3 & 49.8 & 6.5 & 278.0 & 44.9 & 8.3 & -5.8 & -48.4 & 3.2 & 45.6 & 6.8 & 10.4 & 38.6 & 0.6 & contaminated (1) \\
\hline 19 & 27.1 & 11.5 & 63.6 & 9.3 & 321.6 & 23.5 & 0.3 & -6.0 & -41.7 & 3.3 & 8.0 & 18.6 & 14.6 & 156.8 & 0.3 & contaminated (1) \\
\hline 33 & 36.2 & 15.7 & 47.4 & 6.2 & 270.5 & 40.3 & 8.3 & -5.8 & -48.4 & 3.7 & 105.0 & 15.8 & 5.1 & 39.1 & 0.1 & contaminated (1) \\
\hline 27 & 42.4 & 19.9 & 30.2 & 5.7 & 323.4 & 26.0 & 2.0 & -4.5 & -42.8 & 7.0 & -30.0 & 18.6 & 12.5 & 0.0 & 0.1 & end member 2 \\
\hline 18 & 47.3 & 19.4 & 111.5 & 9.2 & 379.0 & 123.8 & 2.8 & -5.1 & -45.4 & 5.6 & -15.2 & 10.4 & 16.5 & 0.0 & 0.2 & \\
\hline $19 \mathrm{~b}$ & 36.3 & 20.5 & 57.1 & 19.8 & 612.6 & 94.4 & 1.6 & -6.1 & -41.0 & 2.5 & 2.0 & 23.2 & 16.7 & & 1.6 & \\
\hline \multicolumn{17}{|l|}{2.3 DHYK area } \\
\hline \multirow[b]{2}{*}{$\begin{array}{l}\text { Sampling No } \\
\text { (Dx) }\end{array}$} & \multicolumn{7}{|c|}{7 Major ions } & \multicolumn{2}{|c|}{2 Stable isotopes } & \multicolumn{2}{|c|}{ Insitu test } & \multicolumn{2}{|c|}{ Nitrate isotopes } & \multicolumn{2}{|c|}{ elevated contaminants } & \\
\hline & $\begin{array}{l}\mathrm{Ca}^{2+} \\
\mathrm{mg} / \mathrm{l}\end{array}$ & $\begin{array}{l}\mathrm{Mg}^{2+} \\
\mathrm{mg} / \mathrm{l}\end{array}$ & $\begin{array}{l}\mathrm{Na}^{+} \\
\mathrm{mg} / \mathrm{l}\end{array}$ & $\begin{array}{c}\mathrm{K}^{+} \\
\mathrm{mg} / \mathrm{l}\end{array}$ & $\begin{array}{c}\mathrm{HCO}_{3}^{-} \\
\mathrm{mg} / \mathrm{l}\end{array}$ & $\begin{array}{c}\mathrm{Cr} \\
\mathrm{mg} / 1\end{array}$ & $\begin{array}{l}\mathrm{SO}_{4}^{-} \\
\mathrm{mg} / \mathrm{l}\end{array}$ & $\begin{array}{l}\delta^{18} \mathrm{O} \\
\left(\%{ }_{00}\right)\end{array}$ & $\begin{array}{l}\delta^{2} \mathrm{H} \\
(\% \%)\end{array}$ & DO & $\begin{array}{c}\text { ORP } \\
\mathrm{mV}\end{array}$ & $\begin{array}{c}\delta^{18} \mathrm{O}_{\mathrm{NO} 3} \\
\left(\%{ }_{00}\right)\end{array}$ & $\begin{array}{c}\delta^{15} \mathrm{~N}_{\mathrm{NO} 3} \\
\left(\%{ }_{00}\right)\end{array}$ & $\begin{array}{c}\text { (3) } \mathrm{CFC}-12 \\
\text { pptv }\end{array}$ & $\begin{array}{l}\text { (4) } \mathrm{NO}_{3}{ }^{-} \\
\mathrm{mg} / \mathrm{l}\end{array}$ & Note \\
\hline 11 & 27.5 & 13.2 & 18.2 & 8.4 & 126.7 & 40.5 & 14.0 & -6.1 & -46.6 & 3.0 & 100.0 & 18.5 & 13.4 & 0.0 & 2.0 & \\
\hline 12 & 37.9 & 19.7 & 22.0 & 10.5 & 305.2 & 7.8 & 9.1 & -6.0 & -46.7 & 3.1 & 72.0 & 8.9 & 18.0 & & 2.8 & \\
\hline $12 \mathrm{a}$ & 38.8 & 19.9 & 22.3 & 11.9 & 305.5 & 8.0 & 9.1 & -4.6 & -38.3 & 3.1 & 38.7 & & & & 3.0 & contaminated (4) \\
\hline $12 \mathrm{~d}$ & 39.0 & 18.7 & 23.1 & 11.8 & 280.7 & 8.6 & 9.3 & -4.6 & -38.3 & 2.0 & -32.0 & & & 0.0 & 3.0 & contaminated (4) \\
\hline $12 \mathrm{f}$ & 38.9 & 19.9 & 22.9 & 12.0 & 299.9 & 8.1 & 9.2 & -5.4 & -42.5 & 2.3 & -60.4 & 33.7 & 38.3 & 0.0 & 3.0 & contaminated (4) \\
\hline 17 & 24.4 & 9.6 & 79.5 & 9.2 & 304.9 & 43.8 & 2.7 & -5.5 & -49.0 & 2.0 & -32.0 & 20.1 & 17.8 & 46.0 & 2.6 & contaminated (1) \\
\hline 13 & 79.1 & 34.5 & 187.1 & 18.5 & 580.1 & 140.5 & 1.5 & -5.8 & -44.7 & 2.9 & -5.2 & & & 0.0 & 3.8 & contaminated (4) \\
\hline $29 \mathrm{a}$ & 16.2 & 7.4 & 162.7 & 22.6 & 395.7 & 40.5 & 6.4 & -5.6 & -43.8 & 2.0 & 0.0 & 19.4 & 21.3 & & 1.3 & \\
\hline 29 & 16.2 & 7.5 & 162.6 & 22.6 & 395.0 & 40.2 & 6.2 & -5.6 & -43.8 & 5.0 & -19.6 & & & 285.1 & 1.1 & contaminated (1) \\
\hline $30 \mathrm{a}$ & 30.6 & 11.6 & 35.3 & 7.0 & 295.9 & 2.0 & 4.8 & -5.7 & -44.0 & 3.0 & -42.2 & 20.1 & 13.4 & 0.0 & 0.9 & end member 2 \\
\hline 43 & 38.2 & 15.2 & 99.8 & 11.3 & 324.3 & 74.4 & 1.8 & -5.8 & -40.7 & 3.9 & -38.7 & 19.4 & 21.7 & 0.0 & 6.6 & contaminated (4) \\
\hline 28 & 33.2 & 13.5 & 53.1 & 10.3 & 308.5 & 27.0 & 6.4 & -5.5 & -42.9 & 3.5 & -39.7 & & & 0.0 & 6.6 & contaminated (4) \\
\hline $28 \mathrm{a}$ & 32.9 & 13.4 & 52.8 & 10.1 & 304.6 & 24.6 & 6.0 & -4.6 & -42.9 & 2.8 & -13.0 & 14.2 & 20.2 & 0.0 & 5.7 & contaminated (4) \\
\hline 41 & 26.8 & 15.1 & 88.8 & 11.3 & 320.2 & 73.8 & 1.8 & -6.0 & -40.6 & 3.3 & 64.4 & 15.2 & 20.8 & 0.0 & 2.4 & \\
\hline 42 & 29.1 & 16.8 & 95.9 & 11.6 & 330.5 & 74.7 & 1.8 & -5.5 & -42.5 & 4.0 & -42.2 & -8.2 & 5.8 & 130.5 & 2.4 & contaminated (1) \\
\hline 32 & 30.2 & 15.2 & 89.9 & 11.5 & 324.4 & 74.2 & 1.9 & -5.0 & -42.9 & 3.0 & -42.2 & 16.4 & 21.4 & 98.2 & 7.8 & contaminated $(1,4)$ \\
\hline 30 & 30.1 & 15.1 & 89.8 & 11.4 & 324.3 & 73.8 & 2.0 & -5.7 & -44.0 & 4.9 & -5.2 & 16.1 & 20.1 & 269.5 & 7.4 & contaminated $(1,4)$ \\
\hline $31 \mathrm{a}$ & 28.2 & 17.9 & 54.0 & 10.7 & 268.4 & 18.5 & 9.3 & -5.4 & -43.3 & 4.7 & -5.2 & 16.4 & 21.4 & 225.0 & 2.4 & contaminated (1) \\
\hline 40 & 31.2 & 15.2 & 97.9 & 12.4 & 326.8 & 75.2 & 1.8 & -5.3 & -40.7 & 2.9 & -13.0 & 16.8 & 8.0 & 17.7 & 5.7 & contaminated $(1,4)$ \\
\hline 31 & 44.4 & 18.7 & 31.8 & 10.2 & 288.9 & 20.7 & 21.7 & -5.9 & -42.9 & 3.1 & 150.0 & -8.4 & 7.2 & 363.8 & 1.1 & contaminated (1) \\
\hline 44 & 44.1 & 18.6 & 31.9 & 10.1 & 289.5 & 18.9 & 20.9 & -6.1 & -46.5 & 3.0 & 188.0 & -6.2 & 9.2 & 300.6 & 1.1 & contaminated (1) \\
\hline
\end{tabular}

Appendix 2. Calculation results of total mixing ratio.

\begin{tabular}{|c|c|c|c|c|c|c|c|c|c|c|c|c|c|c|c|c|c|c|c|}
\hline \multicolumn{20}{|c|}{ a) $\mathrm{CMHI}$ area } \\
\hline \multirow{2}{*}{$\begin{array}{c}\text { Sampling } \\
\text { No }\end{array}$} & \multicolumn{2}{|c|}{$\mathrm{Ca}^{2+}$} & \multicolumn{2}{|c|}{$\mathrm{Mg}^{2+}$} & \multicolumn{2}{|c|}{$\mathrm{Na}^{+}$} & \multicolumn{2}{|c|}{$\mathrm{K}^{+}$} & \multicolumn{2}{|c|}{$\mathrm{HCO}_{3}^{-}$} & \multicolumn{2}{|c|}{$\mathrm{Cl}$} & \multicolumn{2}{|c|}{$\mathrm{SO}_{4}^{-}$} & \multicolumn{2}{|c|}{$\delta^{18} \mathrm{O}$} & \multicolumn{2}{|c|}{$\delta^{2} \mathrm{H}$} & \multirow{2}{*}{$\begin{array}{c}\text { Total } \\
\text { mixing } \\
\text { ratio } \\
\mathrm{m}\end{array}$} \\
\hline & $\mathrm{mg} / \mathrm{l}$ & $\mathrm{m}_{\mathrm{p}}$ & $\mathrm{mg} / \mathrm{l}$ & $m_{p}$ & $\mathrm{mg} / \mathrm{l}$ & $\mathrm{m}_{\mathrm{p}}$ & $\mathrm{mg} / \mathrm{l}$ & $\mathrm{m}_{\mathrm{p}}$ & $\mathrm{mg} / 1$ & $\mathrm{~m}_{\mathrm{p}}$ & $\mathrm{mg} / \mathrm{l}$ & $\mathrm{m}_{\mathrm{p}}$ & $\mathrm{mg} / 1$ & $\mathrm{~m}_{\mathrm{p}}$ & $(\%)$ & $\mathrm{m}_{\mathrm{p}}$ & $(\%)$ & $\mathrm{m}_{\mathrm{p}}$ & \\
\hline 10 & 60.2 & -0.04 & 23.2 & -2.62 & 33.5 & 0.71 & 8.7 & 0.81 & 280.9 & 0.96 & 21.2 & 0.41 & 13.8 & 0.13 & -6.2 & -0.03 & -46.8 & -0.69 & 0.69 \\
\hline 1 & 23.8 & -2.52 & 10.7 & 0.59 & 16.9 & 1.00 & 7.8 & 1.13 & 184.7 & 1.82 & 4.0 & 1.06 & 8.6 & 0.07 & -5.5 & 0.78 & -44.2 & 0.86 & 0.37 \\
\hline 9 & 59.9 & -0.06 & 22.9 & -2.54 & 32.6 & 0.72 & 7.5 & 1.24 & 275.2 & 1.01 & 20.8 & 0.42 & 12.7 & 0.12 & -5.4 & 0.84 & -38.3 & 4.41 & 0.69 \\
\hline 2 & 28.0 & -2.23 & 13.0 & 0.01 & 24.0 & 0.87 & 9.3 & 0.58 & 219.2 & 1.51 & 9.8 & 0.84 & 14.5 & 0.14 & -6.2 & 0.01 & -46.6 & -0.56 & 0.37 \\
\hline $5 \mathrm{a}$ & 28.8 & -2.18 & 12.8 & 0.05 & 23.8 & 0.88 & 9.3 & 0.57 & 217.4 & 1.53 & 8.8 & 0.88 & 14.5 & 0.14 & -6.2 & 0.01 & -45.6 & 0.00 & 0.39 \\
\hline 3 & 27.9 & -2.24 & 13.9 & -0.22 & 23.9 & 0.87 & 9.2 & 0.63 & 217.9 & 1.53 & 9.8 & 0.84 & 15.2 & 0.14 & -5.6 & 0.61 & -44.8 & 0.49 & 0.37 \\
\hline 5 & 68.1 & 0.49 & 26.7 & -3.51 & 86.3 & -0.22 & 14.9 & -1.44 & 295.7 & 0.83 & 104.6 & -2.75 & 54.0 & 0.59 & -5.9 & 0.33 & -45.5 & 0.11 & 0.30 \\
\hline 8 & 59.9 & -0.06 & 23.1 & -2.59 & 32.5 & 0.72 & 7.4 & 1.26 & 279.5 & 0.98 & 20.9 & 0.42 & 13.4 & 0.12 & -5.5 & 0.78 & -44.2 & 0.86 & 0.69 \\
\hline $6 \mathrm{c}$ & 43.9 & -1.15 & 18.9 & -1.51 & 30.9 & 0.75 & 9.9 & 0.36 & 288.4 & 0.90 & 21.7 & 0.39 & 21.9 & 0.22 & -5.7 & 0.53 & -44.7 & 0.58 & 0.49 \\
\hline 6 & 57.0 & -0.26 & 24.1 & -2.84 & 63.1 & 0.19 & 11.5 & -0.20 & 206.7 & 1.63 & 45.2 & -0.50 & 25.2 & 0.26 & -4.7 & 1.60 & -39.9 & 3.45 & 0.48 \\
\hline 4 & 29.0 & -2.17 & 13.2 & -0.05 & 24.9 & 0.86 & 9.5 & 0.53 & 219.4 & 1.51 & 10.0 & 0.83 & 15.5 & 0.15 & -6.1 & 0.05 & -46.5 & -0.52 & 0.38 \\
\hline $4 a$ & 55.8 & -0.34 & 23.8 & -2.77 & 62.5 & 0.20 & 10.9 & 0.01 & 205.4 & 1.64 & 44.2 & -0.46 & 24.1 & 0.25 & -6.1 & 0.03 & -46.5 & -0.53 & 0.47 \\
\hline $6 \mathrm{~b}$ & 45.2 & -1.06 & 19.3 & -1.60 & 32.6 & 0.72 & 10.5 & 0.14 & 290.5 & 0.88 & 21.9 & 0.38 & 22.4 & 0.23 & -5.6 & 0.62 & -44.6 & 0.60 & 0.50 \\
\hline $6 a$ & 44.9 & -1.08 & 19.2 & -1.59 & 31.9 & 0.73 & 10.2 & 0.25 & 289.8 & 0.88 & 20.7 & 0.43 & 21.9 & 0.22 & -5.6 & 0.59 & -44.6 & 0.60 & 0.50 \\
\hline $7 \mathrm{c}$ & 45.2 & -1.06 & 18.8 & -1.49 & 32.6 & 0.72 & 10.5 & 0.14 & 290.5 & 0.88 & 21.9 & 0.38 & 22.4 & 0.23 & -6.1 & 0.03 & -46.3 & -0.41 & 0.50 \\
\hline 7 & 60.8 & 0.00 & 21.0 & -2.04 & 73.6 & 0.00 & 11.2 & -0.11 & 386.9 & 0.01 & 31.8 & 0.01 & 98.1 & 1.09 & -5.9 & 0.26 & -40.7 & 2.96 & 0.58 \\
\hline $7 \mathrm{~b}$ & 60.1 & -0.05 & 24.0 & -2.82 & 33.7 & 0.70 & 9.9 & 0.36 & 285.8 & 0.92 & 21.9 & 0.38 & 13.8 & 0.13 & -6.0 & 0.24 & -40.8 & 2.92 & 0.68 \\
\hline $7 \mathrm{a}$ & 60.6 & -0.02 & 20.8 & -2.00 & 72.9 & 0.01 & 11.1 & -0.07 & 385.1 & 0.03 & 30.4 & 0.06 & 97.9 & 1.09 & -5.9 & 0.28 & -40.8 & 2.92 & 0.59 \\
\hline 47 & 25.1 & -2.43 & 11.1 & 0.48 & 31.6 & 0.74 & 8.9 & 0.72 & 253.5 & 1.21 & 4.0 & 1.06 & 4.0 & 0.02 & -6.5 & -0.38 & -45.5 & 0.11 & 0.33 \\
\hline 46 & 24.8 & -2.45 & 11.1 & 0.49 & 31.2 & 0.75 & 8.9 & 0.73 & 250.8 & 1.23 & 3.9 & 1.06 & 5.9 & 0.04 & -6.0 & 0.17 & -45.5 & 0.07 & 0.32 \\
\hline 45 & 60.8 & 0.00 & 13.0 & 0.00 & 73.7 & 0.00 & 10.9 & 0.00 & 388.5 & 0.00 & 32.0 & 0.00 & 90.8 & 1.01 & -6.2 & 0.01 & -45.6 & 0.00 & 0.57 \\
\hline 12 & 37.9 & -1.56 & 19.7 & -1.72 & 22.0 & 0.91 & 10.5 & 0.15 & 305.2 & 0.74 & 7.8 & 0.92 & 9.1 & 0.07 & -6.0 & 0.14 & -46.7 & -0.63 & 0.49 \\
\hline $12 \mathrm{~d}$ & 39.0 & -1.48 & 18.7 & -1.45 & 23.1 & 0.89 & 11.8 & -0.33 & 280.7 & 0.96 & 8.6 & 0.89 & 9.3 & 0.08 & -4.6 & 1.72 & -38.3 & 4.39 & 0.50 \\
\hline $12 \mathrm{f}$ & 38.9 & -1.49 & 19.9 & -1.77 & 22.9 & 0.89 & 12.0 & -0.40 & 299.9 & 0.79 & 8.1 & 0.91 & 9.2 & 0.07 & -5.4 & 0.85 & -42.5 & 1.87 & 0.50 \\
\hline 1 & 37.2 & -1.61 & 15.7 & -0.70 & 25.0 & 0.85 & 8.9 & 0.73 & 267.8 & 1.08 & 2.0 & 1.14 & 4.6 & 0.02 & -5.4 & 0.85 & -42.5 & 1.87 & 0.51 \\
\hline 15 & 79.3 & 1.26 & 34.6 & -5.53 & 188.3 & -2.01 & 18.6 & -2.80 & 583.3 & -1.74 & 141.3 & -4.14 & 1.6 & -0.01 & -5.5 & 0.78 & -44.9 & 0.45 & 0.10 \\
\hline $15 \mathrm{a}$ & 23.8 & -2.52 & 8.9 & 1.05 & 78.7 & -0.09 & 9.1 & 0.66 & 302.8 & 0.77 & 43.8 & -0.45 & 2.7 & 0.00 & -6.8 & -0.74 & -44.0 & 1.01 & 0.01 \\
\hline 34 & 23.3 & -2.55 & 8.6 & 1.12 & 75.5 & -0.03 & 9.1 & 0.65 & 300.7 & 0.79 & 42.6 & -0.40 & 2.6 & 0.00 & -6.0 & 0.22 & -42.6 & 1.81 & 0.00 \\
\hline $39 \mathrm{~b}$ & 24.2 & -2.49 & 9.6 & 0.87 & 78.5 & -0.08 & 8.8 & 0.76 & 302.7 & 0.77 & 43.4 & -0.43 & 2.5 & 0.00 & -6.5 & -0.42 & -42.2 & 2.04 & 0.00 \\
\hline
\end{tabular}


Appendix 2. Continuation.

\begin{tabular}{|c|c|c|c|c|c|c|c|c|c|c|c|c|c|c|c|c|c|c|c|}
\hline \multicolumn{20}{|c|}{ b) RCK area } \\
\hline \multirow{2}{*}{$\begin{array}{c}\text { Sampling } \\
\text { No }\end{array}$} & \multicolumn{2}{|c|}{$\mathrm{Ca}^{2+}$} & \multicolumn{2}{|c|}{$\mathrm{Mg}^{2+}$} & \multicolumn{2}{|c|}{$\mathrm{Na}^{+}$} & \multicolumn{2}{|c|}{$\mathrm{K}^{+}$} & \multicolumn{2}{|c|}{$\mathrm{HCO}_{3}{ }^{-}$} & \multicolumn{2}{|c|}{$\mathrm{Cl}$} & \multicolumn{2}{|c|}{$\mathrm{SO}_{4}^{-}$} & \multicolumn{2}{|c|}{$\delta^{18} \mathrm{O}$} & \multicolumn{2}{|c|}{$\delta^{2} \mathrm{H}$} & \multirow{2}{*}{$\begin{array}{c}\text { Total } \\
\text { mixing } \\
\text { ratio } \\
\mathrm{m}\end{array}$} \\
\hline & $\mathrm{mg} / 1$ & $\mathrm{~m}_{\mathrm{p}}$ & $\mathrm{mg} / 1$ & $\mathrm{~m}_{\mathrm{p}}$ & $\mathrm{mg} / 1$ & $\mathrm{~m}_{\mathrm{p}}$ & $\mathrm{mg} / 1$ & $\mathrm{~m}_{\mathrm{p}}$ & $\mathrm{mg} / \mathrm{l}$ & $\mathrm{m}_{\mathrm{p}}$ & $\mathrm{mg} / 1$ & $\mathrm{~m}_{\mathrm{p}}$ & $\mathrm{mg} / \mathrm{l}$ & $\mathrm{m}_{\mathrm{p}}$ & $\left(\%{ }_{00}\right)$ & $\mathrm{m}_{\mathrm{p}}$ & $\left(\%{ }_{00}\right)$ & $\mathrm{m}_{\mathrm{p}}$ & \\
\hline 23 & 21.5 & -1.86 & 8.3 & 5.68 & 10.5 & 3.66 & 2.3 & -1.06 & 157.2 & 4.17 & 2.0 & -3.23 & 3.2 & 0.04 & -6.2 & 4.44 & -51.5 & -9.33 & 0.17 \\
\hline $22 \mathrm{a}$ & 39.2 & -0.29 & 9.2 & 5.25 & 13.5 & 3.51 & 5.0 & -0.22 & 160.8 & 4.08 & 0.6 & -3.43 & 1.1 & -0.03 & -6.1 & 4.18 & -41.0 & 1.87 & 0.12 \\
\hline 22 & 39.9 & -0.22 & 7.4 & 6.12 & 6.9 & 3.85 & 3.0 & -0.85 & 110.6 & 5.34 & 2.7 & -3.14 & 0.5 & -0.05 & -6.3 & 4.53 & -50.8 & -8.49 & 0.10 \\
\hline 21 & 39.2 & -0.29 & 9.3 & 5.18 & 13.6 & 3.50 & 5.0 & -0.22 & 170.4 & 3.84 & 0.7 & -3.41 & 1.2 & -0.02 & -6.3 & 4.55 & -51.1 & -8.81 & 0.12 \\
\hline $33 a$ & 36.1 & -0.56 & 15.5 & 2.14 & 48.9 & 1.64 & 6.3 & 0.18 & 275.9 & 1.19 & 44.2 & 2.45 & 8.1 & 0.19 & -5.8 & 3.34 & -48.4 & -5.97 & 0.25 \\
\hline 25 & 36.3 & -0.54 & 14.9 & 2.44 & 48.2 & 1.68 & 6.5 & 0.23 & 280.1 & 1.09 & 44.1 & 2.43 & 8.7 & 0.21 & -6.0 & 3.80 & -48.9 & -6.50 & 0.27 \\
\hline 20 & 33.2 & -0.82 & 25.0 & -2.53 & 55.6 & 1.29 & 13.6 & 2.44 & 375.4 & -1.31 & 42.6 & 2.23 & 0.8 & -0.04 & -5.4 & 2.36 & -45.8 & -3.20 & 0.03 \\
\hline 24 & 25.2 & -1.52 & 14.1 & 2.86 & 16.8 & 3.33 & 7.1 & 0.43 & 233.1 & 2.27 & 1.3 & -3.33 & 6.4 & 0.14 & -6.1 & 4.01 & -48.8 & -6.39 & 0.25 \\
\hline $24 \mathrm{~b}$ & 25.2 & -1.53 & 14.1 & 2.83 & 16.1 & 3.37 & 7.1 & 0.43 & 230.2 & 2.34 & 1.2 & -3.34 & 6.3 & 0.13 & -5.4 & 2.36 & -45.8 & -3.20 & 0.25 \\
\hline $19 \mathrm{c}$ & 38.0 & -0.40 & 18.1 & 0.87 & 50.8 & 1.55 & 7.8 & 0.63 & 298.3 & 0.63 & 60.7 & 4.67 & 0.6 & -0.04 & -5.5 & 2.63 & -47.0 & -4.48 & 0.02 \\
\hline $18 \mathrm{a}$ & 46.5 & 0.36 & 19.2 & 0.32 & 110.5 & -1.59 & 9.1 & 1.05 & 375.4 & -1.31 & 121.7 & 12.87 & 2.7 & 0.02 & -4.5 & 0.00 & -42.8 & 0.00 & 0.00 \\
\hline $20 \mathrm{a}$ & 36.1 & -0.56 & 16.3 & 1.74 & 49.8 & 1.60 & 6.5 & 0.23 & 278.0 & 1.14 & 44.9 & 2.55 & 8.3 & 0.19 & -5.8 & 3.29 & -48.4 & -5.97 & 0.25 \\
\hline 19 & 27.1 & -1.36 & 11.5 & 4.10 & 63.6 & 0.87 & 9.3 & 1.11 & 321.6 & 0.04 & 23.5 & -0.35 & 0.3 & -0.05 & -6.0 & 3.72 & -41.7 & 1.12 & 0.03 \\
\hline 33 & 36.2 & -0.55 & 15.7 & 2.04 & 47.4 & 1.72 & 6.2 & 0.15 & 270.5 & 1.33 & 40.3 & 1.92 & 8.3 & 0.20 & -5.8 & 3.25 & -48.4 & -5.98 & 0.26 \\
\hline 27 & 42.43 & 0.00 & 19.85 & 0.00 & 80.24 & 0.00 & 5.72 & 0.00 & 323.41 & 0.00 & 26.03 & 0.00 & 2.00 & 0.00 & -4.47 & 0.00 & -42.77 & 0.00 & 0.10 \\
\hline 18 & 47.3 & 0.43 & 19.4 & 0.23 & 111.5 & -1.65 & 9.2 & 1.07 & 379.0 & -1.40 & 123.8 & 13.16 & 2.8 & 0.02 & -5.1 & 1.50 & -45.4 & -2.84 & 0.00 \\
\hline $19 \mathrm{~b}$ & 36.3 & -0.55 & 20.5 & -0.32 & 57.1 & 1.22 & 19.8 & 4.36 & 612.6 & -7.26 & 94.4 & 9.21 & 1.6 & -0.01 & -6.1 & 4.18 & -41.0 & 1.87 & 0.00 \\
\hline \multicolumn{20}{|c|}{ c) DHYK area } \\
\hline \multirow{2}{*}{$\begin{array}{c}\text { Sampling } \\
\text { No*) }\end{array}$} & \multicolumn{2}{|c|}{$\mathrm{Ca}^{2+}$} & \multicolumn{2}{|c|}{$\mathrm{Mg}^{2+}$} & \multicolumn{2}{|c|}{$\mathrm{Na}^{+}$} & & & & & & & & & $\delta^{18}$ & & $\delta^{2} \mathrm{H}$ & & $\begin{array}{c}\text { Total } \\
\text { mixing }\end{array}$ \\
\hline & $\mathrm{mg} / \mathrm{l}$ & $\mathrm{m}_{\mathrm{p}}$ & $\mathrm{mg} / \mathrm{l}$ & $\mathrm{m}_{\mathrm{p}}$ & $\mathrm{mg} / \mathrm{l}$ & $\mathrm{m}_{\mathrm{p}}$ & $\mathrm{mg} / \mathrm{l}$ & $\mathrm{m}_{\mathrm{p}}$ & $\mathrm{mg} / \mathrm{l}$ & $\mathrm{m}_{\mathrm{p}}$ & $\mathrm{mg} / 1$ & $\mathrm{~m}_{\mathrm{p}}$ & $\mathrm{mg} / \mathrm{l}$ & $\mathrm{m}_{\mathrm{p}}$ & $(\%)$ & $\mathrm{m}_{\mathrm{p}}$ & $(\% / 00)$ & $\mathrm{m}_{\mathrm{p}}$ & $\mathrm{m}$ \\
\hline 11 & 27.5 & -0.75 & 13.2 & -5.97 & 18.2 & 1.13 & 8.4 & 2.90 & 126.7 & 2.59 & 40.5 & 0.50 & 14.0 & 0.25 & -6.1 & -0.47 & -46.6 & 2.97 & 0.31 \\
\hline 12 & 37.9 & -0.02 & 19.7 & 13.79 & 22.0 & 1.07 & 10.5 & 0.81 & 305.2 & 0.25 & 7.8 & 0.97 & 9.1 & 0.15 & -6.0 & -0.33 & -46.7 & 3.00 & 0.23 \\
\hline $12 a$ & 38.8 & 0.04 & 19.9 & 14.36 & 22.3 & 1.07 & 11.9 & -0.61 & 305.5 & 0.25 & 8.0 & 0.97 & 9.1 & 0.15 & -4.6 & 1.97 & -38.3 & -1.20 & 0.23 \\
\hline $12 d$ & 39.0 & 0.06 & 18.7 & 10.67 & 23.1 & 1.06 & 11.8 & -0.51 & 280.7 & 0.57 & 8.6 & 0.96 & 9.3 & 0.16 & -4.6 & 1.97 & -38.3 & -1.20 & 0.24 \\
\hline $12 f$ & 38.9 & 0.05 & 19.9 & 14.39 & 22.9 & 1.06 & 12.0 & -0.70 & 299.9 & 0.32 & 8.1 & 0.97 & 9.2 & 0.15 & -5.4 & 0.66 & -42.5 & 0.91 & 0.23 \\
\hline 17 & 24.4 & -0.97 & 9.6 & -16.73 & 79.5 & 0.28 & 9.2 & 2.11 & 304.9 & 0.25 & 43.8 & 0.45 & 2.7 & 0.02 & -5.5 & 0.45 & -49.0 & 4.14 & 0.04 \\
\hline 13 & 79.1 & 2.88 & 34.5 & 58.48 & 187.1 & -1.21 & 18.5 & -7.22 & 580.1 & -3.36 & 140.5 & -0.97 & 1.5 & -0.01 & -5.8 & 0.05 & -44.7 & 2.01 & 0.10 \\
\hline $29 \mathrm{a}$ & 16.2 & -1.55 & 7.4 & -23.39 & 162.7 & -0.87 & 22.6 & -11.45 & 395.7 & -0.94 & 40.5 & 0.50 & 6.4 & 0.10 & -5.6 & 0.37 & -43.8 & 1.54 & 0.05 \\
\hline 29 & 16.2 & -1.55 & 7.5 & -23.33 & 162.6 & -0.87 & 22.6 & -11.41 & 395.0 & -0.93 & 40.2 & 0.50 & 6.2 & 0.09 & -5.6 & 0.36 & -43.8 & 1.55 & 0.04 \\
\hline 30a & 30.6 & -0.54 & 11.6 & -10.64 & 35.3 & 0.89 & 7.0 & 4.32 & 295.9 & 0.37 & 2.0 & 1.06 & 4.8 & 0.06 & -5.7 & 0.12 & -44.0 & 1.64 & 0.14 \\
\hline 43 & 38.2 & 0.00 & 15.2 & 0.00 & 99.8 & 0.00 & 11.3 & 0.00 & 324.3 & 0.00 & 74.4 & 0.00 & 1.8 & 0.00 & -5.8 & 0.01 & -40.7 & 0.00 & 0.00 \\
\hline 28 & 33.2 & -0.35 & 13.5 & -4.97 & 53.1 & 0.65 & 10.3 & 1.02 & 308.5 & 0.21 & 27.0 & 0.69 & 6.4 & 0.10 & -5.5 & 0.45 & -42.9 & 1.09 & 0.14 \\
\hline $28 \mathrm{a}$ & 32.9 & -0.37 & 13.4 & -5.30 & 52.8 & 0.65 & 10.1 & 1.21 & 304.6 & 0.26 & 24.6 & 0.73 & 6.0 & 0.09 & -4.6 & 2.00 & -42.9 & 1.09 & 0.14 \\
\hline 41 & 26.8 & -0.80 & 15.1 & -0.15 & 88.8 & 0.15 & 11.3 & 0.00 & 320.2 & 0.05 & 73.8 & 0.01 & 1.8 & 0.00 & -6.0 & -0.25 & -40.6 & -0.08 & 0.01 \\
\hline 42 & 29.1 & -0.64 & 16.8 & 5.00 & 95.9 & 0.05 & 11.6 & -0.30 & 330.5 & -0.08 & 74.7 & 0.00 & 1.8 & 0.00 & -5.5 & 0.45 & -42.5 & 0.91 & 0.01 \\
\hline 32 & 30.2 & -0.56 & 15.2 & 0.00 & 89.9 & 0.14 & 11.5 & -0.16 & 324.4 & 0.00 & 74.2 & 0.00 & 1.9 & 0.00 & -5.0 & 1.25 & -42.9 & 1.09 & 0.00 \\
\hline 30 & 30.1 & -0.57 & 15.1 & -0.15 & 89.8 & 0.14 & 11.4 & -0.10 & 324.3 & 0.00 & 73.8 & 0.01 & 2.0 & 0.00 & -5.7 & 0.10 & -44.0 & 1.64 & 0.00 \\
\hline 31a & 28.2 & -0.71 & 17.9 & 8.27 & 54.0 & 0.63 & 10.7 & 0.63 & 268.4 & 0.73 & 18.5 & 0.82 & 9.3 & 0.16 & -5.4 & 0.66 & -43.3 & 1.32 & 0.20 \\
\hline 40 & 31.2 & -0.49 & 15.2 & 0.00 & 97.9 & 0.03 & 12.4 & -1.12 & 326.8 & -0.03 & 75.2 & -0.01 & 1.8 & 0.00 & -5.3 & 0.77 & -40.7 & 0.00 & 0.01 \\
\hline 31 & 44.4 & 0.44 & 18.7 & 10.79 & 31.8 & 0.94 & 10.2 & 1.10 & 288.9 & 0.46 & 20.7 & 0.79 & 21.7 & 0.42 & -5.9 & -0.19 & -42.9 & 1.09 & 0.46 \\
\hline 44 & 44.1 & 0.42 & 18.6 & 10.45 & 31.9 & 0.94 & 10.1 & 1.21 & 289.5 & 0.46 & 18.9 & 0.81 & 20.9 & 0.40 & -6.1 & -0.57 & -46.5 & 2.92 & 0.44 \\
\hline
\end{tabular}

Appendix 3. Calculation results of mixing ratio of nitrate concentration and their nitrate isotopes.

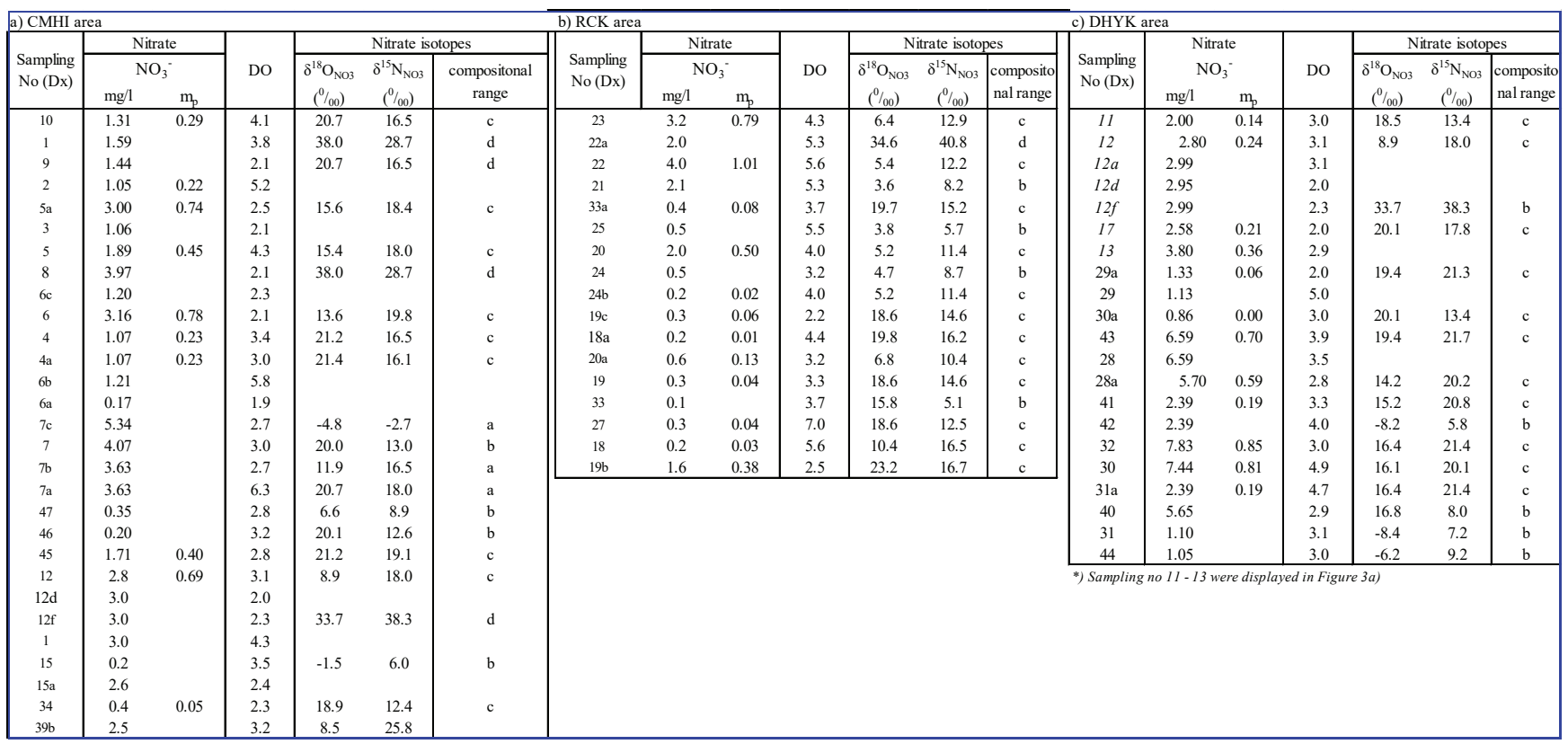

